Article

\title{
Climate Change Demands Adaptive Management of Urban Lakes: Model-Based Assessment of Management Scenarios for Lake Tegel (Berlin, Germany)
}

\author{
Robert Ladwig ${ }^{1,2, *}$ (1) , Eiichi Furusato ${ }^{3}$, Georgiy Kirillin ${ }^{1}$, Reinhard Hinkelmann ${ }^{2}$ and \\ Michael Hupfer 1 \\ 1 Leibniz-Institute of Freshwater Ecology and Inland Fisheries, 12587 Berlin, Germany; \\ kirillin@igb-berlin.de (G.K.); hupfer@igb-berlin.de (M.H.) \\ 2 Chair of Water Resources Management and Modeling of Hydrosystems, Technische Universität Berlin, \\ 13355 Berlin, Germany; reinhard.hinkelmann@wahyd.tu-berlin.de \\ 3 Department of Civil and Environmental Engineering, Saitama University, Saitama 338-8570, Japan; \\ furusato@mail.saitama-u.ac.jp \\ * Correspondence: ladwig@igb-berlin.de; Tel.: +49-30-64-181-741
}

Received: 1 January 2018; Accepted: 7 February 2018; Published: 10 February 2018

\begin{abstract}
Lakes are known to be strongly affected by climate change as a result of their sensitivity to atmospheric forcing. The combined response of urban lakes to climatic changes and to urbanization of the catchment may be further altered by water quality management measures. We studied Lake Tegel in Berlin, Germany as a representative urban lake profoundly influenced by intense water management measures and a resulting complex hydrodynamic situation: Lake Tegel is fed by nutrient-rich river discharges and effluents from a phosphorus elimination plant (PEP). We estimated changes in water temperatures, the Wedderburn number, and the buoyancy frequency, as well as concentrations of dissolved oxygen and phosphate under climate change using a one-dimensional vertical hydrodynamic model coupled to a water quality model. Further, we investigated how four management scenarios with varying discharges of the PEP could affect the lake system. In all simulations, water temperatures increased and summer stratification extended. The modeling results demonstrated that the water management system buffers the high nutrient supply from the river inflow and can effectively mitigate negative effects of climate change on Lake Tegel, thus highlighting its importance for the lake ecosystem.
\end{abstract}

Keywords: GLM-AED2; water resources management; thermal stratification; climate change; phosphorus elimination plant

\section{Introduction}

Climate change is one of the major stressors for ecosystems [1,2]. More frequent extreme weather events, rising air temperatures, intense precipitation affecting erosion, and changing atmospheric circulation patterns are the future challenges ecosystems have to cope with [3]. In particular, lakes are expected to act as sentinels to climate change [4-6]. Urban lakes are crucial freshwater resources for a secure water supply and adequate sanitation, as well as for recreational activities. Water management of urban lakes is an important compartment of the respective catchments and its water cycle [7]. Adaptive water management measures have the potential to mitigate effects caused by climate change as well as nutrient and contaminant loadings to lake or reservoir systems [8-10]. The effect of climate change on lake physics, ecosystem services and ecosystem structures has been intensively studied in the last decades (e.g., [11,12]). Numerous authors have 
suggested the future dominance of cyanobacteria in lakes as a result of climate change increasing water temperatures and affecting the stratification strength [13-15]. Therefore, high water temperatures in summer in conjunction with a high buoyancy frequency suggest an increased probability for the formation of cyanobacteria blooms. Further, vertical thermal stratification was found to be particularly sensitive to the changing meteorological conditions [16-18], but the specific impact on lakes can be spatially and temporally diverse [19]. The among-lake coherence to climate change, particularly in the surface layers, is a well-established observation, but the individual properties of a lake can, to a certain degree, affect how deeper water layers respond to climate change [20,21]. This individual response of a lake to climate change can be diverse even for regionally proximate lake systems [22].

In contrast to rural or less anthropogenically affected surface waters, urban lakes, which are important parts of the urban water cycle, are often deeply intertwined with technical interfaces in the form of water management systems [23]. A semi-closed water cycle is common in megalopolises [24], in which case the treated effluents of wastewater treatment plants (WWTPs) are discharged into urban surface waters where they are further abstracted for drinking water production, for example, via bank filtration, before entering the WWTP again. The strong impact of water management measures on the system is a shared characteristic of both urban lakes and freshwater reservoirs. It is up for debate to what degree the urban management system, similarly to reservoirs, can also mitigate a lake's response to climate change. The impact of climate change in conjunction with urbanization will have a profound effect on lakes, with increased mass loadings of nutrients and contaminants originating from the urban catchment [25-27]. Finding effective adaptive strategies of water management systems to diminish the vulnerability of the freshwater system to climate change is an essential task for freshwater resource managers worldwide [28,29]. Numerical modeling can be used to obtain a better understanding of how water management measures can adapt to ongoing challenges caused by climate change [30,31].

Although several studies have pointed out the importance of adaptive water management measures in times of climate change, for instance, for regional lakes and watersheds [32-34], locally in the region of Berlin, Germany [35] or in general [36,37], our focus was on the adaption of a specific management measure, the phosphorus elimination plant (PEP) at Lake Tegel in Berlin, Germany. Lake Tegel underwent a strong eutrophication period from 1950 to 1985 as a result of high external loadings of nutrients as well as heavy metals originating from an upstream sewage farm, resulting in blooms of cyanobacteria and the loss of the lake's submerged macrophyte population [38,39]. To restore the lake system, which was and still is crucial for Berlin's drinking water production, the lake was subjected to various management measures: (1) the construction of an upstream WWTP, (2) the launch of the PEP treating inflowing waters, (3) the construction of a lake pipeline for bypassing outflowing water back to the PEP to maintain a steady discharge, and (4) the launch of hypolimnetic aerators in the deep water basin [40]. Because of Lake Tegel's utter importance for Berlin's drinking water supply and for recreational activities, the lake was intensively investigated and monitored in the last decades. Past sediment studies investigated Lake Tegel's sediment affinity to an additional supply of iron and concluded that most of the iron was bound to sedimentary sulphur [41] as well as that the past management measures had a profound effect on Lake Tegel's sediment composition, resulting in a heterogeneity between different sites [42]. Previous studies have also highlighted that the reduction of external loads was the main mechanism for the restoration of Lake Tegel, particularly the construction of the WWTP and the PEP [38,43]. In contrast, the performance of the hypolimnetic aerators was concluded to be more similar to bubble plume generators and therefore caused an increased mixing between hypolimnion and epilimnion instead of hypolimnetic aeration [44]. In recent years, modeling studies have proved that Lake Tegel is very sensitive to river-induced mixing caused by wind and that an optimal management to keep phosphate as well as pharmaceutical concentrations in the lake low was not feasible $[45,46]$.

The objectives of our study were (1) to determine if a one-dimensional (1D) vertical model configuration is applicable for the evaluation of management scenarios for Lake Tegel, (2) to check if an assumed shift of the lake type to a monomictic mixing regime and the formation of favorable 
conditions for cyanobacteria can happen as a result of climate change, and (3) if the PEP can mitigate the impact of climate change on Lake Tegel in the near future. In contrast to previous modeling studies on Lake Tegel [43-45], our study was focused on the simulated projection of the impact of climate change on Lake Tegel by using projected meteorological data and the simulation of physical variables as well as nutrients.

\section{Materials and Methods}

\subsection{Study Site}

Lake Tegel $\left(52.5761^{\circ}, 13.2533^{\circ}\right)$ is a dimictic shallow lake located in Berlin, Germany. The lake consists of a northern basin with water depths of up to $16 \mathrm{~m}$ and a southwestern basin, which is characterized by islands and shallow water depths of around 2 to $4 \mathrm{~m}$ (Figure 1). The lake volume is 26.1 Mio. $\mathrm{m}^{3}$, and the mean depth is $6.6 \mathrm{~m}$. The lake receives nutrient-rich discharges from the River Havel in the southwest (mean discharge for 2008-2014 of $\bar{Q}=12 \mathrm{~m}^{3} \mathrm{~s}^{-1}$ ) and the treated effluents of a WWTP from the northeast (mean discharge for 2008-2014 of $\bar{Q}=2.5 \mathrm{~m}^{3} \mathrm{~s}^{-1}$ ), which are further processed by the upstream PEP. Additional management measures are an active lake pipeline, which collects water close to the southwestern outflow and bypasses it to the elimination plant to maintain a minimum discharge and to dilute influents, and several groundwater abstraction wells around the lake, as well as hypolimnetic aerators in the main basin.

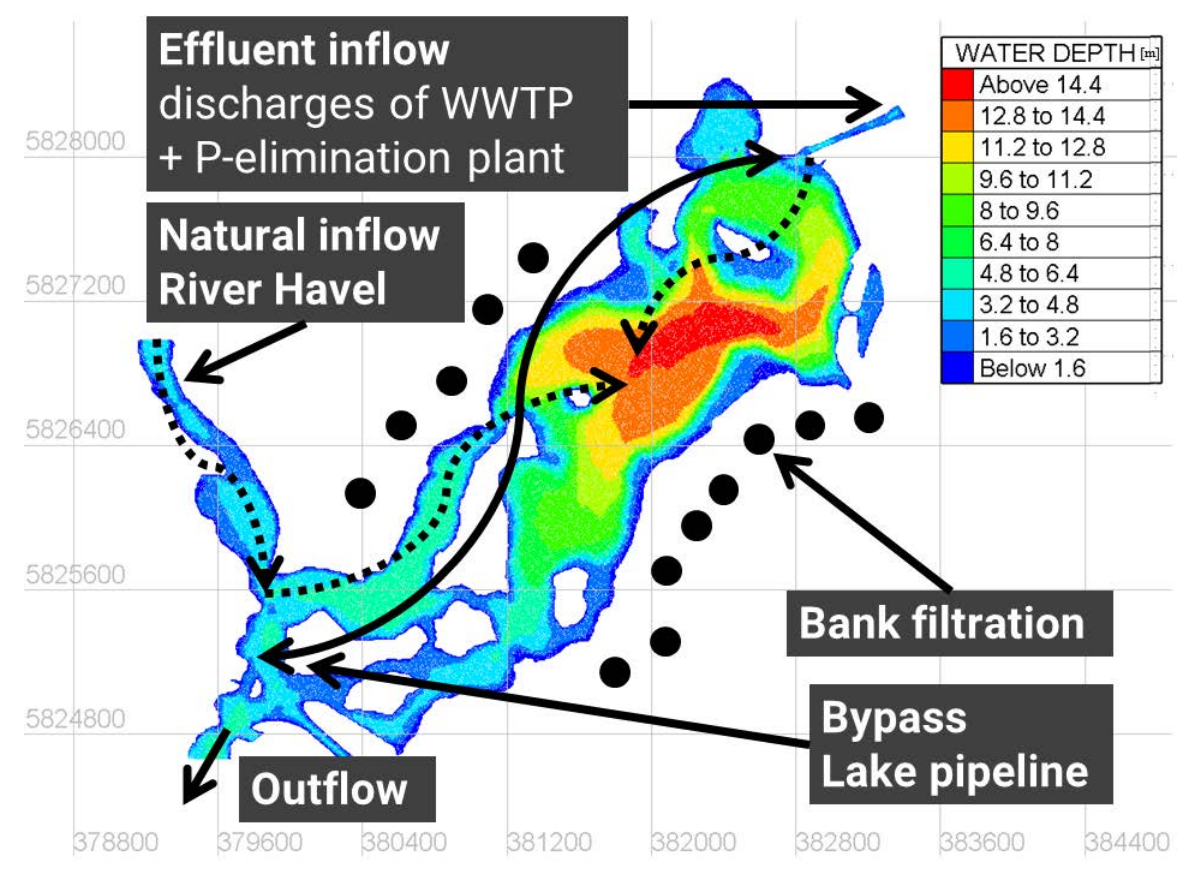

Figure 1. Bathymetric map of Lake Tegel including the main inflow conditions (water depths in meters, positions of groundwater abstraction wells are idealized, white spots represent islands, and the black line represents the lake pipeline).

\subsection{Model Description and Input Data}

To check if applying a 1D vertical model is a reasonable approach for Lake Tegel, we evaluated the ratio $R$ of the internal Rossby radius $R_{i}(\mathrm{~m})$ to the lake width $B(\mathrm{~m})$ and the lake number $L_{N}[-]$, which was calculated with the LakeAnalyzer software tool [47]. The former checked the effect of the earth's rotation on the lake $[48,49]$, and the latter calculated the ratio of stabilizing forces to destabilizing forces affecting the water column $[50,51]$. The internal Rossby $R_{i}$ radius was calculated using summer field data measured in 2016-2017, during which a two-layer stratification existed: 


$$
R_{i}=\frac{c_{w s}}{f}=\frac{\sqrt{g^{\prime} * h}}{f} \simeq 2016 \mathrm{~m}
$$

where $c_{w s}$ is the internal wave speed $\left(\mathrm{m} \mathrm{s}^{-1}\right) ; f$ is the Coriolis acceleration $\left(\mathrm{s}^{-1}\right) ; g^{\prime}=g \cdot \Delta \rho / \rho_{0}$ is the reduced gravitational acceleration $\left(\mathrm{m} \mathrm{s}^{-2}\right) ; g$ is the gravitational acceleration $\left(\mathrm{m} \mathrm{s}^{-2}\right) ; \Delta \rho$ is the density difference between hypolimnion and epilimnion $\left(\mathrm{kg} \mathrm{m}^{-3}\right) ; \rho_{0}$ is the reference water density, which equals $1000 \mathrm{~kg} \mathrm{~m}^{-3} ; h=\frac{h_{1} h_{2}}{h_{1}+h_{2}}$ is the equivalent lake depth (m); $h_{1}$ is the eplimnion thickness (m); and $h_{2}$ is the hypolimnion thickness (m). Subsequently, we calculated the ratio $R$ :

$$
R=\frac{R_{i}}{B} \simeq 2.0
$$

As input for the calculation of the lake number, we used observed field water temperature data from 2008 to 2014 measured by the Senate of Berlin at the deepest site, as well as daily wind data from the weather station Berlin-Tegel. The 1D assumption can be used for lake systems with $R>1$ [48] and $L_{N} \gg 1$ [51]. With a calculated ratio $R$ of 2.0, indicating an absence of rotational effects, and an average value $L_{N} \sim 5.8$, suggesting a horizontal density structure of the lake, Lake Tegel matched these assumptions.

As a modeling tool, we applied the General Lake Model (GLM v. 2.0.0). GLM is a vertical 1D hydrodynamic model employing a flexible Lagrangian layer structure to adapt the thickness of individual layers during mixing processes [52]. GLM incorporates water balance, surface energy budget, meteorology, vertical mixing, stratification and boundary flow dynamics. The atmospheric component of the long-wave radiation was calculated on the basis of cloud cover data. We used the implemented coupling with the Aquatic Ecodynamics Model Library (AED2 v. 1.0) to simulate water quality processes [53]. We kept the water quality configuration simple by focusing on the inorganic biogeochemical variables phosphate and nitrate. Here, phosphate represents the soluble reactive phosphorus fraction ortho-phosphate, $\mathrm{o}-\mathrm{PO}_{4}-\mathrm{P}$, and nitrate represents $\mathrm{NO}_{3}-\mathrm{N}$. To represent biological primary production, we included one phytoplankton group representing diatoms in the model, which are a dominant species in Lake Tegel [54].

In the following paragraph, we list the main conceptual model assumptions of the respective boundary conditions to simulate Lake Tegel. We used a constant sediment flux model, which acted as a sink/source for dissolved oxygen, nitrate and phosphate for each layer under the dependence of water temperatures and the respective area ratio to the benthic area. As open lateral boundary conditions, we prescribed daily inflow rates and loadings from the PEP (first inflow, representing the lake pipeline by the combined discharge of both the elimination plant and the lake pipeline) and the River Havel (second inflow). Assuming complete mixing of the River Havel inflow because of its narrow and shallow inlet between several islands, we interpolated the monthly water temperature values of the inflow. This was done by linear regression between the River Havel water temperature data and the air temperature data as well as between the River Havel water temperature data and PEP water temperature data. For each day, the maximum value of either regression was used as the water temperature for the River Havel inflow to ensure a shallow entrainment into Lake Tegel. The model included two outflow conditions: a simplified outflow by bank filtration with a constant discharge, and the main lake outflow in the southwest, which was implemented as an overflow boundary. We neglected the artificial aerators on the basis of their uncertain operation mode. Meteorological data were provided with a daily resolution.

For the model calibration and validation, we used field data from the period 2008-2014. The data are summarized in Table 1 together with the applied preprocessing steps. Further calculations and evaluations were done by using MATLAB R2017a (The MathWorks Inc., Natick, MA, USA), and lake-specific variables were calculated using the LakeAnalyzer software [47]. An overview of the modeling framework is given in Figure 2, and the specific methods are explained in the following sections. 
Table 1. Model boundary data: missing data were assumed to be constant to the next neighbor; values under detection limit were set to half of the detection limit concentration.

\begin{tabular}{|c|c|c|c|}
\hline Boundary Condition & Variable & Source & Preprocessing \\
\hline Morphology & $\begin{array}{l}\text { Area }\left(\mathrm{m}^{2}\right) \\
\text { Depth }(\mathrm{m})\end{array}$ & SB & \\
\hline Meteorology & $\begin{array}{c}\text { Air temperature }\left({ }^{\circ} \mathrm{C}\right) \\
\text { Relative humidity }(\%) \\
\text { Wind speed }\left(\mathrm{m} \mathrm{s}^{-1}\right)(\text { height of } 10 \mathrm{~m}) \\
\text { Precipitation }\left(\mathrm{m} \mathrm{d}^{-1}\right) \\
\text { Cloud cover }(-) \\
\text { Shortwave radiation }\left(\mathrm{W} \mathrm{m}^{-2}\right)\end{array}$ & $\begin{array}{l}\text { WT } \\
\text { WT } \\
\text { WT } \\
\text { WT } \\
\text { WT } \\
\text { CP }\end{array}$ & Hourly shortwave radiation was transformed to mean daily values \\
\hline Inflow & $\begin{array}{c}\text { Discharge }\left(\mathrm{m}^{3} \mathrm{~s}^{-1}\right) \\
\text { Water temperature }\left({ }^{\circ} \mathrm{C}\right) \\
\text { Salinity }\left(\mathrm{mg}^{-1}\right)\end{array}$ & $\begin{array}{l}\text { TO, PEP } \\
\text { OH, PEP } \\
\text { OH, PEP }\end{array}$ & Salinity was derived from measured electrical conductivity using factor 0.65 [55] \\
\hline & $\begin{array}{l}\text { Dissolved oxygen conc. }\left(\mathrm{mmol} \mathrm{m}^{-3}\right) \\
\text { Phosphate conc. }\left(\mathrm{mmol} \mathrm{m}^{-3}\right) \\
\text { Nitrate conc. }\left(\mathrm{mmol} \mathrm{m}^{-3}\right) \\
\text { Ammonium conc. }\left(\mathrm{mmol} \mathrm{m}^{-3}\right) \\
\text { Dissolved organic carbon conc. }\left(\mathrm{mmol} \mathrm{m}^{-3}\right) \\
\text { Particulate organic carbon conc. }\left(\mathrm{mmol} \mathrm{m}^{-3}\right) \\
\text { Silica conc. }\left(\mathrm{mmol} \mathrm{m}{ }^{-3}\right)\end{array}$ & $\begin{array}{l}\text { OH, N } \\
\text { OH, PEP } \\
\text { OH, PEP } \\
\text { OH, PEP } \\
\text { OH, PEP } \\
\text { OH, PEP }\end{array}$ & Assumed to be constant \\
\hline Outflow & Discharge $\left(\mathrm{m}^{3} \mathrm{~s}^{-1}\right)$ & BWB & Constant mean discharge was used \\
\hline $\begin{array}{l}\text { First calibration } \\
\text { Second calibration }\end{array}$ & $\begin{array}{l}\text { Water temperature }\left({ }^{\circ} \mathrm{C}\right) \\
\text { Dissolved oxygen conc. }\left(\mathrm{mmol} \mathrm{m}^{-3}\right) \\
\text { Nitrate conc. }\left(\mathrm{mmol} \mathrm{m}^{-3}\right) \\
\text { Phosphate conc. }\left(\mathrm{mmol} \mathrm{m}^{-3}\right)\end{array}$ & $\begin{array}{l}\text { SB } \\
\text { SB } \\
\text { SB } \\
\text { SB }\end{array}$ & $\begin{array}{l}\text { Deepest site of Lake Tegel } \\
\text { Deepest site of Lake Tegel } \\
\text { Deepest site of Lake Tegel } \\
\text { Deepest site of Lake Tegel }\end{array}$ \\
\hline
\end{tabular}

* SB: Senate of Berlin; WT: Weather station Berlin-Tegel (DWD); CP: Climate station Potsdam (DWD); TO: Stream gauge Tegelort (Senate of Berlin); PEP: Phosphorus elimination plant Tegel (Berlin Water Company); OH: Oberhavel, Konradshöhe (Senate of Berlin); N: Nordgraben (Senate of Berlin); BWB: Berlin Water Company. 


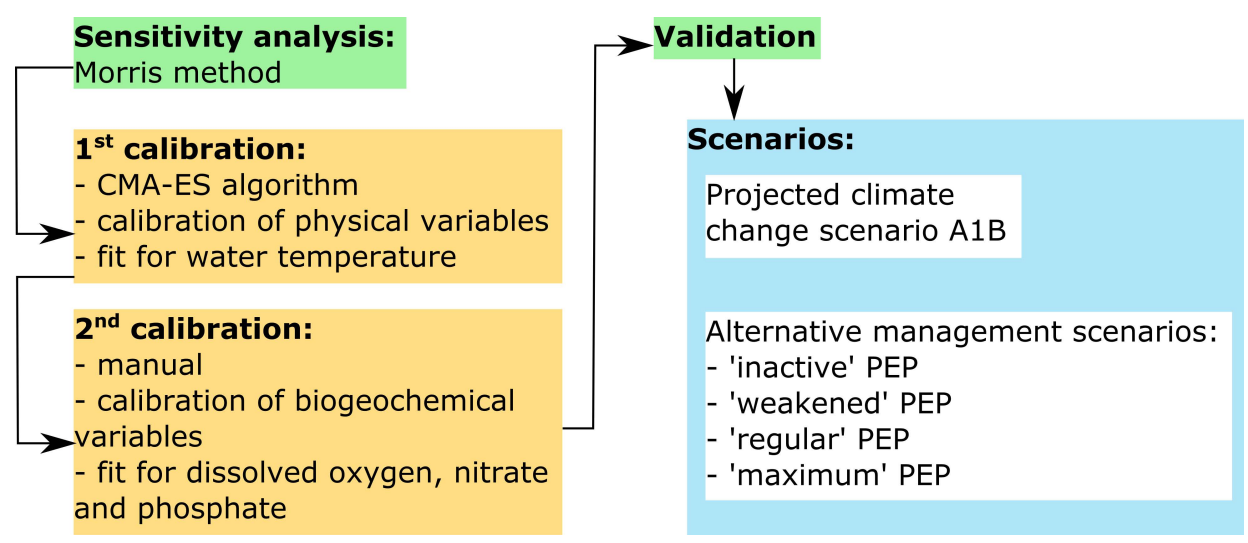

Figure 2. Flowchart illustrating the main modeling framework.

\subsection{Calibration and Validation}

We used the Morris method $[56,57]$ to globally identify sensitive model variables for subsequent use in the calibration procedure. The method gives a qualitative estimation of the respective variables' sensitivity by calculating the average of the absolute elementary effect (EE). The elementary effects are relative changes of the model outcome when changing a respective variable, and the Morris method ranks the variables according to their sensitivity. Using this procedure, we investigated the sensitivity of a group of 24 model variables by calculating the model outcome, which is represented here by the root-mean-square error (RMSE) between simulated and observed water temperatures in 2008, which were measured at the depth range of 0.5 to $14 \mathrm{~m}$ (below $1 \mathrm{~m}$ under the surface with a distance between measurements of $1 \mathrm{~m}$ ). The group of model variables consisted of those given in Table 2 under "Calibrated by CMA-ES", except for the penalty factors and the shortwave radiation factor $F_{s w}$. Instead, the group checked for sensitivity included the length and width of the outflow, $L_{\text {out }}$ and $W_{\text {out }}$, as well as the light extinction coefficient $K_{W}\left(\mathrm{~m}^{-1}\right)$. For each variable, a normal distribution was assumed, characterized by an arithmetic mean equal to the respective default value and a $\sigma$ of $1 / 6$ of the arithmetic mean. The sensitivity analysis was run for 20 iterations. We conducted the calibration in two steps. First we used the recent data from 2008 to 2011 ( $n=4$ years) to calibrate physical lake parameters by comparing simulated water temperatures with field temperatures. Although the variables were calibrated globally, each year was evaluated individually by simulating the period from April to March of the next year, using the first field data of water temperatures and salinities as initial conditions. Prior to the calibration, the model variables were rescaled into the variable space [0;10]. We applied upper and lower boundary conditions to each variable and started with the default values as initial values $X_{0}$ [52]. We applied the derivative-free, evolutionary Covariance Matrix Adaption Evolution Strategy (CMA-ES) algorithm [58] to the objective function $O F$, effectively trying to minimize the normalized root-mean-square error (NRMSE) of the water temperature:

$$
O F=\min \left(\frac{\sqrt{\frac{\sum\left(T_{\text {sim }}-T_{\text {field }}\right)^{2}}{n}}}{\max \left(T_{\text {field }}\right)-\min \left(T_{\text {field }}\right)}\right)
$$

where $n$ is the number of observations. We chose 24 variables (Table 2) for the automatic calibration procedure, focusing on those that had a high average elementary effect determined by the Morris method. Further, we explored whether the optimization would benefit from a penalizing filter to better represent the river mixing due to wind dynamics. The river-induced mixing is strongest during easterly wind conditions [45]. The wind data obtained from the weather station Berlin-Tegel suggested that during the months of January, March, April, May and October, the lake experiences conditions that are favorable for river-induced mixing. To implement this information in the model, we added two extra calibration variables, which were used as multipliers affecting the River Havel 
discharge corresponding to the above-mentioned favorable months. We ran the calibation several times with changing values for the population size (number of candidate solutions per iteration) and the maximum nunmber of iterations to account for poor optimization runs converging to local minima.

Table 2. Model variables (initial values either refer to values given in exemplary files or from the GLM and AED2 manuals [52,53]; model values are the actual values used in the calculations).

\begin{tabular}{|c|c|c|c|}
\hline Variable & Description & $\begin{array}{l}\text { Initial } \\
\text { Value }\end{array}$ & $\begin{array}{l}\text { Model } \\
\text { Value }\end{array}$ \\
\hline \multicolumn{4}{|c|}{ Calibrated by Covariance Matrix Adaption Evolution Strategy } \\
\hline$\varphi_{P E P}\left({ }^{\circ}\right)$ & Streambed slope, phosphorus elimination plant (PEP) & 1.0 & 1.1 \\
\hline$\varphi_{\text {Havel }}\left({ }^{\circ}\right)$ & Streambed slope, Havel & 1.0 & 0.52 \\
\hline$\alpha_{P E P}\left({ }^{\circ}\right)$ & Stream half angle, PEP & 65 & 73 \\
\hline$\alpha_{\text {Havel }}\left({ }^{\circ}\right)$ & Stream half angle, Havel & 65 & 30 \\
\hline$C_{D, P E P}\left({ }^{\circ}\right)$ & Drag coefficient, PEP & 0.016 & 0.018 \\
\hline$C_{D, \text { Havel }}\left({ }^{\circ}\right)$ & Drag coefficient, Havel & 0.016 & 0.026 \\
\hline$Q_{P E P}(-)$ & Inflow factor, PEP & 1 & 2 \\
\hline$Q_{\text {Havel }}(-)$ & Inflow factor, Havel & 0.5 & 0.6 \\
\hline$k_{\text {eastwind }}(-)$ & Penalty for East/South wind conditions & 1.0 & 0.74 \\
\hline$k_{\text {remaining }}(-)$ & Penalty for non-East/South wind conditions & 1.0 & 0.96 \\
\hline$Q_{\text {Out }}(-)$ & Outflow factor bank filtration & 1.0 & 0.5 \\
\hline$H_{\text {Out }}(\mathrm{m})$ & Outflow elevation bank filtration & 29 & 29 \\
\hline$C_{K}(-)$ & Convective overturn & 0.125 & 0.2 \\
\hline$C_{W}(-)$ & Wind stirring & 0.23 & 0.34 \\
\hline$C_{S}(-)$ & Shear production & 0.20 & 0.25 \\
\hline$C_{T}(-)$ & Unsteady turbulence & 0.51 & 0.38 \\
\hline$C_{K H}(-)$ & Kelvin-Helmholtz billowing & 0.30 & 0.23 \\
\hline$C_{H Y P}(-)$ & Hypolimnetic turbulence & 0.50 & 0.17 \\
\hline$F_{\text {wind }}(-)$ & Wind factor & 1.0 & 1.5 \\
\hline$F_{\text {rain }}(-)$ & Rain factor & 1.0 & 1.4 \\
\hline$F_{s w}(-)$ & Shortwave radiation factor & 1.0 & 1.2 \\
\hline$C_{E}(-)$ & Latent heat transfer & 0.0013 & 0.00266 \\
\hline$C_{H}(-)$ & Sensible heat transfer & 0.0013 & 0.001 \\
\hline$C_{M}(-)$ & Transfer of momentum & 0.0013 & 0.00107 \\
\hline \multicolumn{4}{|l|}{ Manually calibrated } \\
\hline$F^{o x y} \max \left(\mathrm{mmol} \mathrm{m}^{-2} \mathrm{~d}^{-1}\right)$ & Max sediment flux, dissolved oxygen & -15 & -20 \\
\hline$F^{\text {nit }}{ }_{\max }\left(\mathrm{mmol} \mathrm{m}^{-2} \mathrm{~d}^{-1}\right)$ & Max sediment flux, nitrate & -0.5 & -0.1 \\
\hline$F^{a \max }\left(\mathrm{mmol} \mathrm{m}^{-2} \mathrm{~d}^{-1}\right)$ & Max sediment flux, ammonium & 3.0 & 17 \\
\hline$F^{\text {phs }}{ }_{\max }\left(\mathrm{mmol} \mathrm{m}^{-2} \mathrm{~d}^{-1}\right)$ & Max sediment flux, phosphate & 0.2 & 0.04 \\
\hline$\Theta^{\text {oxy }}{ }_{\text {sed }}(-)$ & Temperature multiplier for oxygen sediment flux & 1.08 & 1.03 \\
\hline$\Theta^{D O C}$ miner $(-)$ & $\begin{array}{l}\text { Temperature multiplier for dissolved organic carbon (DOC) } \\
\text { mineralization }\end{array}$ & 1.08 & 1.08 \\
\hline$R^{D O C}$ miner $\left(\mathrm{d}^{-1}\right)$ & Max rate of DOC mineralization & 0.001 & 0.002 \\
\hline$K_{\text {sed }}^{\text {oxy }}\left(\mathrm{mmol} \mathrm{m}^{-3}\right)$ & $\begin{array}{l}\text { Half saturation constant for oxygen dependence of sediment } \\
\text { oxygen flux }\end{array}$ & 150 & 50 \\
\hline$K^{D O C}{ }_{s e d}\left(\mathrm{mmol} \mathrm{m}^{-3}\right)$ & $\begin{array}{l}\text { Half saturation constant for oxygen dependence of sediment } \\
\text { DOC flux }\end{array}$ & 31.25 & 32 \\
\hline \multicolumn{4}{|l|}{ Phytoplankton } \\
\hline$\omega_{p h y}\left(\mathrm{md}^{-1}\right)$ & Sedimentation rate & -0.86 & -0.1 \\
\hline$R_{\text {growth }}\left(\mathrm{d}^{-1}\right)$ & Growth rate at $20^{\circ} \mathrm{C}$ & 3 & 2.75 \\
\hline$T_{s t d}\left({ }^{\circ} \mathrm{C}\right)$ & Standard temperature & 20 & 20 \\
\hline$T_{\text {opt }}\left({ }^{\circ} \mathrm{C}\right)$ & Optimum temperature & 25 & 25 \\
\hline$T_{\max }\left({ }^{\circ} \mathrm{C}\right)$ & Maximum temperature & 32 & 32 \\
\hline$\Theta_{\text {phy }}^{\text {growth }(-)}$ & Temperature multiplier for growth & 1.06 & 1.06 \\
\hline$\Theta^{\text {phy }}{ }_{\text {respiration }}(-)$ & Temperature multiplier for respiration & 1.12 & 1.12 \\
\hline$K_{N}\left(\mathrm{mmol} \mathrm{m}^{-3}\right)$ & Half saturation concentration for nitrogen & 3.5 & 3.5 \\
\hline$K_{P}\left(\mathrm{mmol} \mathrm{m}^{-3}\right)$ & Half saturation concentration for phosphorus & 0.15 & 0.15 \\
\hline
\end{tabular}

In the second step, we manually calibrated the biogeochemical variables (nine variables; Table 2) to adjust the fit between the simulated and measured concentrations of dissolved oxygen, nitrate and phosphate for each year from 2008 to 2011. We used field data of dissolved oxygen, nitrate and phosphate as initial conditions for each year. The field data depicted fluxes of dissolved oxygen below 
the summer thermocline but also stable thermal conditions. We assumed that these oxygen fluxes were caused by the activation of Lake Tegel's artificial aerators, which we wanted to neglect in the model. Therefore, we limited the calibration of the biogeochemical variables by only including days during early summer when oxygen depletion happened. To account for primary production, we included diatoms as one phytoplankton species in the model using default values, although we slightly adjusted the values for the diatom sedimentation and growth rates (see Section 3.1). We quantified the fit by using the RMSE and the Nash-Sutcliffe coefficient of efficiency (NSE). We validated the findings of the calibration of the physical and biogeochemical variables for the years 2012, 2013 and 2014 ( $n=3$ years).

\subsection{Scenarios}

To project how climate change will affect Lake Tegel, we combined a climate change scenario with different management scenarios of the PEP. We used a realization of future meteorological conditions generated by Wetterlagen-basierte Regionalisierungsmethode 2010 (WETTREG2010) [59-61] for the weather station Berlin-Tegel until 2100. WETTREG2010 is a statistical method to calculate regional weather data by combining past data of the individual station with projections by global climate models. Here, the data followed the A1B scenario based on ECHAM5/MPI-OM T63L31 from the Intergovernmental Panel on Climate Change, assuming a balanced use between fossil and non-fossil energy sources, rapid economic growth combined with the development of efficient technologies, and a peak of the global population in the middle of this century [62]. WETTREG2010 projects future daily meteorological variables for air temperature, relative humidity, wind speed, precipitation and cloud cover. As a simplification, we used the daily mean shortwave radiation averaged over the specific day of the year in the period 2008-2014 as future values. The WETTREG2010 method created several independent time series, each with a good replication of future climate variability. Instead of an ensemble, we utilized only one projected time series for the evaluation of the future impact of climate change on Lake Tegel. We investigated four management scenarios to quantify the impact of alternative discharge regimes of the PEP under climate change on the lake system. In the following, the mean annual discharge and its respective standard deviation are stated, whereas in each management scenario, either a constant value (inactive and maximum scenarios) or a time series of daily mean discharges averaged over the specific day of the year in the stated time periods (weakened and regular scenarios) were used:

1. Inactive: discharge is set to a constant value of $0 \mathrm{~m}^{3} \mathrm{~s}^{-1}$, and the elimination plant becomes deactivated: $Q=0 \pm 0.0 \mathrm{~m}^{3} \mathrm{~s}^{-1}$.

2. Weakened: for each year, we used the mean daily discharges from the period 1996-2001, when the lake pipeline, supporting the elimination plant, was deactivated: $Q=1.47 \pm 0.3 \mathrm{~m}^{3} \mathrm{~s}^{-1}$.

3. Regular: for each year, we used the mean daily discharges from our field data for 2008-2014: $Q=2.53 \pm 0.4 \mathrm{~m}^{3} \mathrm{~s}^{-1}$.

4. Maximum: for each year, we set the daily discharge to a constant value of $3.5 \mathrm{~m}^{3} \mathrm{~s}^{-1}$ : $Q=3.5 \pm 0.0 \mathrm{~m}^{3} \mathrm{~s}^{-1}$.

For water temperatures, salinity, and concentrations of dissolved oxygen, ammonium, nitrate, phosphate, dissolved organic carbon (DOC), particulate organic carbon (POC) and silica, we calculated the daily mean values averaged over the specific day of the year in the period 2008-2014 and assumed the future values to have a steady annual pattern. We evaluated the impact of the scenarios on the individual years 2020, 2040, 2060, 2080 and 2100 by quantifying the following:

- $\quad$ The surface water temperatures $\left({ }^{\circ} \mathrm{C}\right)$.

- The differences between surface and bottom water temperatures as a proxy for stratified conditions $[63,64]$; here we used the simulated bottom water temperatures at a depth of $6.5 \mathrm{~m}$, which represented the mean depth of Lake Tegel.

- The duration of stratification between onset and breakdown; we determined the onset and breakdown of stratification as the day on which the temperature difference was over or under $1^{\circ} \mathrm{C}$ and the mean temperature difference of the next 14 days was also over or under $1^{\circ} \mathrm{C}$. 
- The thermocline depths (using the LakeAnalyzer software); the thermocline depths were normalized between 0 and 1 .

- The dimensionless Wedderburn number $W=\frac{g^{\prime} h^{2}}{u_{*}^{2}(L / 2)}$ [65], where $h$ is the depth of the mixed layer (m), $u_{*}$ is the water friction velocity due to wind stress $\left(\mathrm{m} \mathrm{s}^{-1}\right), g^{\prime}$ is the previously explained reduced gravitational acceleration, and $L$ is the fetch length $(\mathrm{m}) ; \mathrm{W}$ is an indicator for the breakdown of lake stratification [66] (using the LakeAnalyzer software).

- The buoyancy frequency $N^{2}=\frac{g}{\rho} \frac{d \rho}{d z}\left(\mathrm{~s}^{-2}\right)$ as an indicator for phytoplankton habitat conditions (using the LakeAnalyzer software).

- The duration of critical bottom oxygen concentrations under $2 \mathrm{mg} \mathrm{L}^{-1}$; we determined the start and end date of oxygen depletion as the day on which the mean oxygen concentration at depths from 10 to $15 \mathrm{~m}$ was over or under $2 \mathrm{mg} \mathrm{L}^{-1}$ and the mean oxygen concentration of the next 14 days was also over or under $2 \mathrm{mg} \mathrm{L}^{-1}$.

Each year was run from March 15 until December 31 of the respective year, and we assumed mixed initial conditions with uniform vertical profiles of water temperatures $\left(5^{\circ} \mathrm{C}\right)$, dissolved oxygen $\left(10 \mathrm{mg} \mathrm{L}^{-1}\right)$, nitrate $\left(2.6 \mathrm{mg} \mathrm{L}^{-1}\right)$ and phosphate concentrations $\left(0 \mu \mathrm{g} \mathrm{L}^{-1}\right)$, which were assumed from past field data.

\section{Results}

\subsection{Sensitivity Analysis, Calibration and Validation}

The Morris method attributed the highest EEs to the bulk aerodynamic coefficient for the wind factor $F_{\text {wind }}$ (EE: 0.5), the latent heat transfer $C_{E}$ (EE: 0.2) and the sensible heat transfer $C_{H}$ (EE: 0.2) (Figure 3). The next sensitive parameters were the inflow factors of the PEP and the River Havel, $Q_{P E P}$ and $Q_{\text {Havel }}$. We included most of investigated parameters because of their similar EEs. We dropped the length and width of the outflow as well as the light extinction coefficient because of their low sensitivity for the model outcome. Instead we added the wind penalty variables and a factor for the shortwave radiation for the calibration. During the first calibration step, which aimed to adjust the water temperatures, the best result was achieved by a CMA-ES run over 500 iterations with a population size of 10 . The biogeochemical variables were calibrated manually in a second calibration step by checking the respective NSEs of dissolved oxygen, nitrate and phosphate concentrations. Further, we changed the sedimentation rate of diatoms $\omega_{\text {phy }}$ to $-0.1 \mathrm{~m}^{-1 a y^{-1}}$ [67] and manually adjusted the growth rate $R_{\text {growth }}$ to 2.75 day $^{-1}$. An overview of the final model parameters is given in Table 2. 


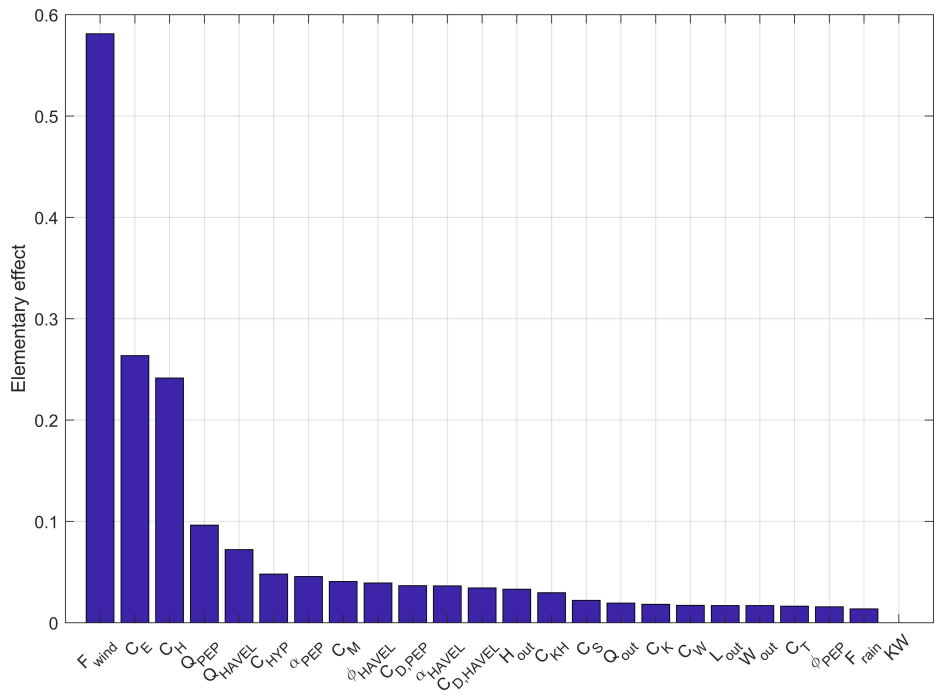

Figure 3. Elementary effects of the parameters derived by the Morris method (variable symbols are explained in Table 2; $L_{\text {out }}$ and $W_{\text {out }}$ represent outflow length $(\mathrm{m})$ and width (m), respectively; $K W$ is the light extinction coefficient).
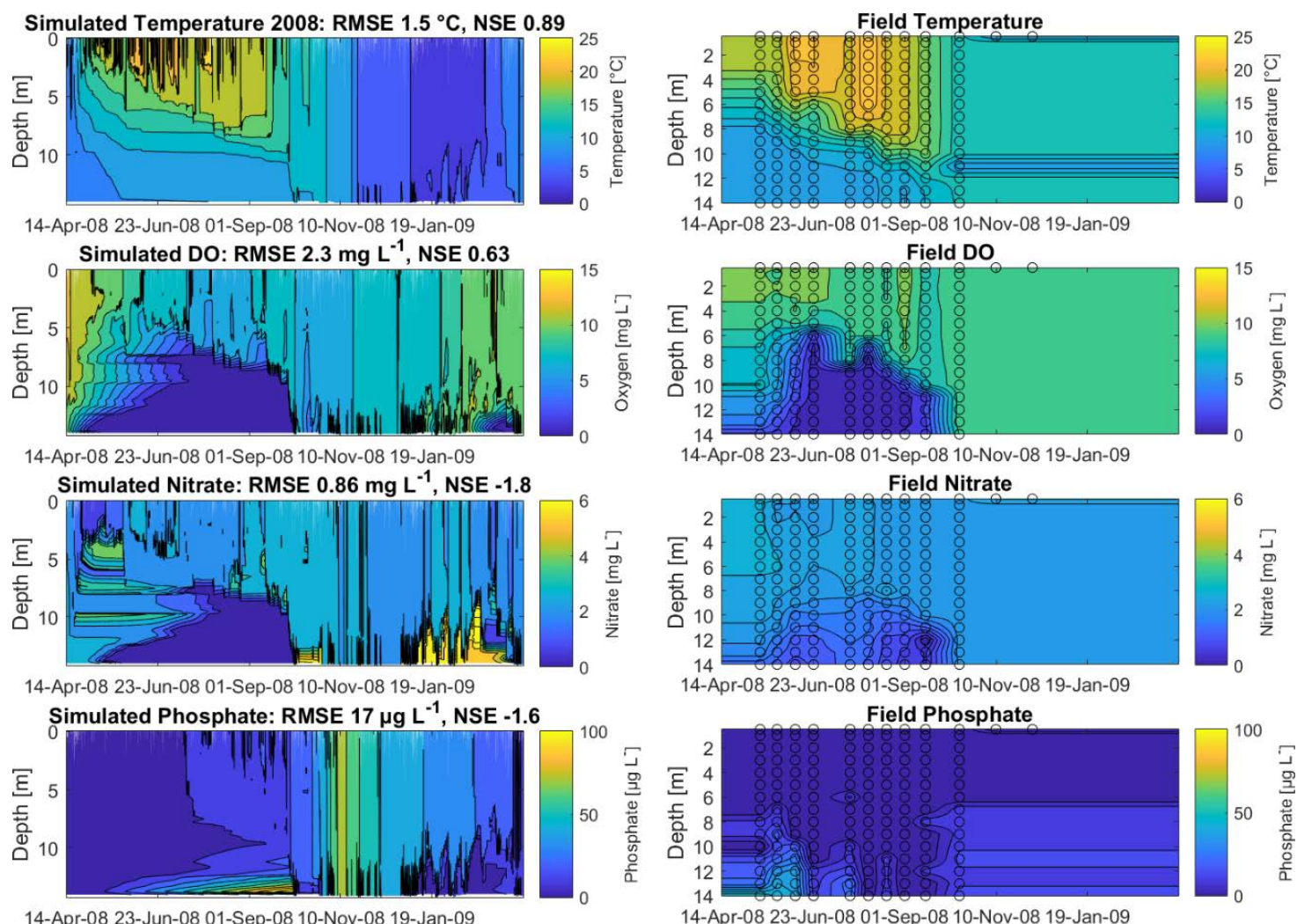

Figure 4. Contour plots for 2008, expressing the simulated dynamics of water temperature $\left({ }^{\circ} \mathrm{C}\right)$, dissolved oxygen $\left(\mathrm{mg} \mathrm{L}^{-1}\right)$, nitrate $\left(\mathrm{mg} \mathrm{L}^{-1}\right)$ and phosphate concentrations $\left(\mu \mathrm{g} \mathrm{L}^{-1}\right)$, as well as linear interpolated field data; the calculated root-mean-square errors (RMSE) and Nash-Sutcliffe coefficients of efficiency (NSE) are given for the total water column; the open circles represent available measured data. 
Calibration of physical and biogeochemical variables
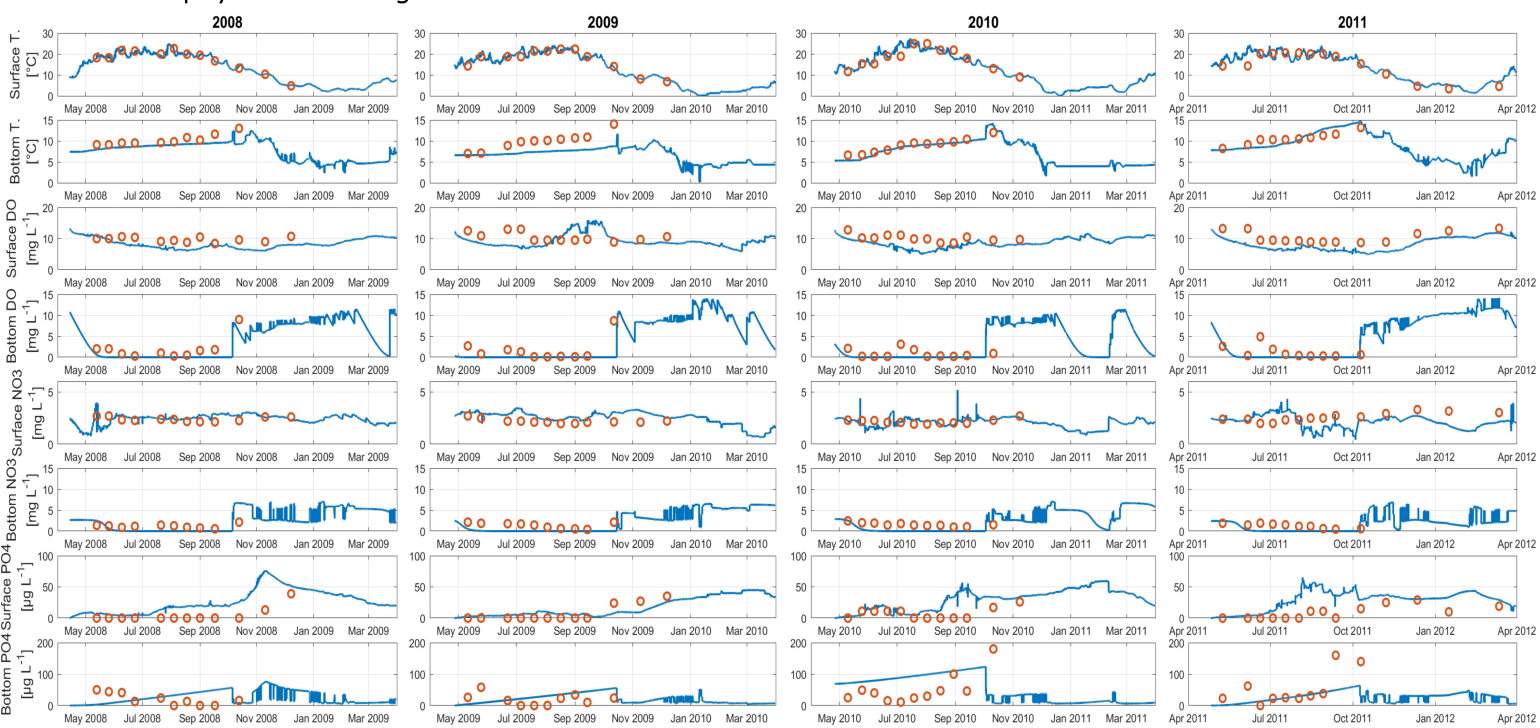

Validation
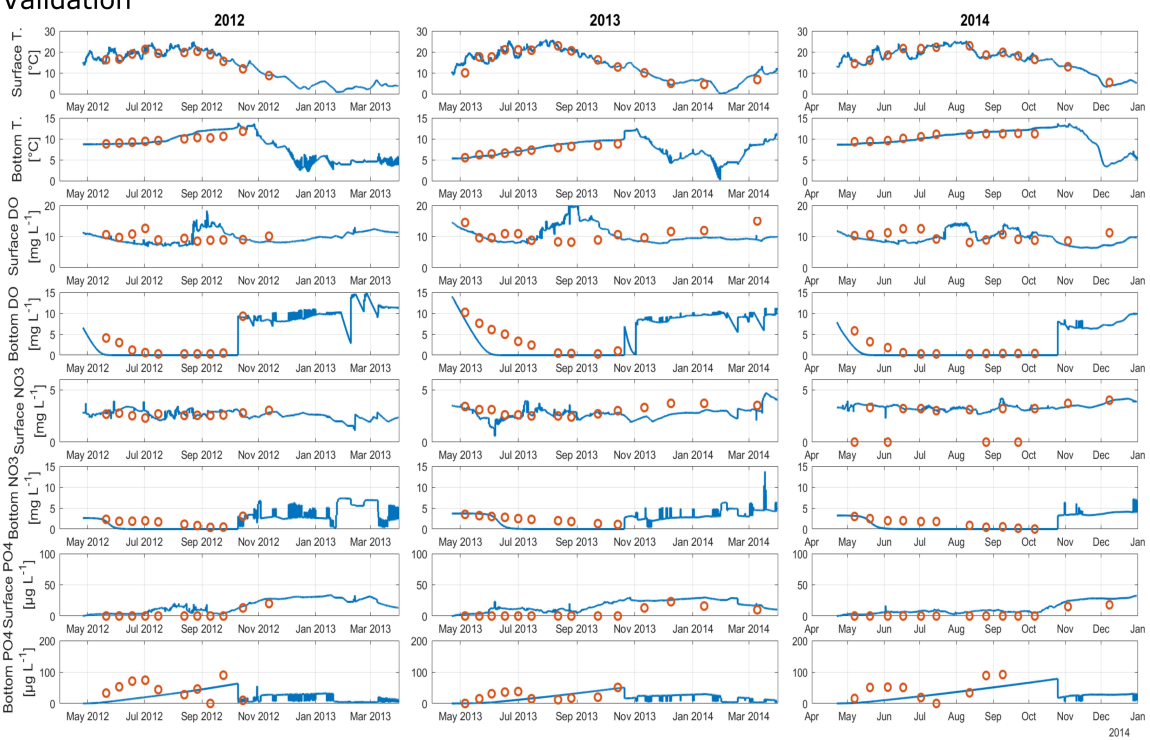

Figure 5. Time series expressing the model performance of water temperature $\left({ }^{\circ} \mathrm{C}\right)$, dissolved oxygen $\left(\mathrm{mg} \mathrm{L}^{-1}\right)$, phosphate $\left(\mu \mathrm{g} \mathrm{L}^{-1}\right)$ and nitrate concentrations $\left(\mathrm{mg} \mathrm{L}^{-1}\right)$; blue lines represent simulated results and red open circles represent field data; surface and bottom represent depths of 2 and $14 \mathrm{~m}$, respectively.

The calibrated years 2008, 2009, 2010 and 2011 achieved NSEs for water temperatures of 0.89 , $0.84,0.9$ and 0.83 , respectively (Figure 4 and Appendix A, Figure A1A-C, showing the hydraulic and water quality dynamics produced by the calibrated model). For dissolved oxygen, the fit between the simulated and field data, with NSEs for 2008, 2009, 2010 and 2011 of 0.63, 0.57, 0.59 and 0.59, respectively, was sufficient. Here the oxygen depletion during summer at the bottom was adequately replicated, whereas the simulated oxygen concentrations in the surface layer were below the measured oxygen concentrations (Figure 4, here shown for 2008). Surface oxygen peaks during the summer season were achieved by simulated blooms of diatoms enabling an internal biological production of oxygen. Although the RMSEs for nitrate for the years 2008-2011 over the whole water column were low, between $0.84 \mathrm{mg} \mathrm{L}^{-1}$ and $1.1 \mathrm{mg} \mathrm{L}^{-1}$, the NSEs were negative. The fit between measured and simulated phosphate was similar to the fit of nitrate: the RMSEs were between $12 \mu \mathrm{g} \mathrm{L}^{-1}$ and $27 \mu \mathrm{g} \mathrm{L}^{-1}$ and the NSEs were negative. The simulated surface temperatures were in very 
good agreement with the field data, whereas there were discrepancies between the simulated and measured bottom water temperatures (Figure 5, showing the fit between measured and simulated data). The depth-specific time series of surface as well as bottom nitrate concentrations depicted that the bottom nitrate concentrations were depleted during summer, whereas in the field, there was still an abundance of nitrate. Still, for most years, the RMSE of simulated to measured bottom nitrate concentrations was only about $0.4 \mathrm{mg} \mathrm{L}^{-1}$ (Appendix A, Table A1). During summer, the surface phosphate concentrations were mostly overestimated, whereas the model was able to replicate the surface phosphate concentrations during the mixing events in autumn. The model was able to simulate a similar range of the measured sediment phosphate flux, although there were temporal discrepancies. The model reproduced the annual stratification patterns of the shallow dimictic lake and was capable of reproducing the seasonal patterns of the nutrients, particularly the general depletion of oxygen and nitrogen concentrations and an internal phosphate flux during summer, as well as the replenishment of bottom layers with oxygen and nitrate concentrations in autumn.

The results for the validated years were similar to the results for the calibrated years. The years 2012, 2013 and 2014 achieved NSEs for water temperatures of 0.87, 0.85 and 0.87 and for dissolved oxygen of $0.56,0.24$ and 0.73 (Appendix A, Figure A1D-F). The bottom nitrate concentrations of all validated years were underestimated (Figure 5). The replication of bottom phosphate concentrations was in a good agreement for 2012 and 2013. In 2014, the bottom phosphate fluxes were underestimated (RMSE: $29 \mathrm{mg} \mathrm{L}^{-1}$; Appendix A, Table A1).

\subsection{Climate Change and Alternative Management Scenarios}

The median, maximum and minimum surface water temperatures were increasing over all management scenarios before reaching levels in 2100 that were similar to those for 2040 (Figure 6A). In all scenarios, the highest median water temperatures were projected in the years 2060 and 2080. Because of this general temperature trend in all management scenarios, for the visualization of the time series of buoyancy frequency and phosphate concentrations, we only investigated 2020, 2060 and 2100 (Figure 6F,H). All scenarios with an active PEP projected similar water temperature differences (Figure 6B). The water temperature differences peaked in 2080 before declining at the end of the century. Compared to the other management scenarios, the inactive management scenario projected the highest maximum and median values of water temperature differences between surface and bottom layers in 2040, 2060 and 2080. The stratification period extended in all scenarios, with a shift of the stratification onset from the middle of April to late March (Figure 6C). In the inactive scenario, the results of the relative thermocline depth showed signs of a disappearance of the winter stratification period (Figure 6D). Here, the thermocline still reached the maximum depth of Lake Tegel in December, whereas the other three scenarios determined a developing thermocline beginning in December, depicting a stratification in winter. Further, when the discharges of the PEP were increased (weakened, regular and maximum), an increased thermocline deepening could be observed between late August and September, which vanished again in the middle of September. Nonetheless, this short thermocline deepening period reduced the successive time of the summer stratification period. The simulation showed that during the prolongation of the stratification, 2060 and 2080, there were only short periods when the thermocline reached the mean lake depth. The changes in the calculated lake-wide Wedderburn number were similar for the regular and maximum scenarios, with higher values in 2020 and 2080 (Figure 6E). In the inactive as well as weakened scenarios, the Wedderburn numbers increased strongly until 2080 before decreasing to a similar level as in the other two scenarios. Here, the inactive scenario projected the highest mean as well as maximum values of the Wedderburn number, which were mostly over 1 . The inactive scenario projected higher buoyancy frequencies over $10^{-2} \mathrm{~s}^{-2}$ compared to the other scenarios (Figure $6 \mathrm{~F}$ ). In all scenarios, the buoyancy frequency was well over $10^{-4} \mathrm{~s}^{-2}$ from April to October. In all scenarios, 2100 showed a slightly longer duration of the buoyancy frequency over $10^{-3} \mathrm{~s}^{-2}$ until the end of September. The duration of a critical oxygen depletion in bottom layers was similar over all scenarios (Figure 6G). The inactive scenario projected 
a slightly longer oxygen depletion duration in 2060 and 2080 compared to the other scenarios. The weakened, regular and maximum scenarios projected phosphate peaks during the summer months that were similar to a projected winter phosphate plateau (Figure $6 \mathrm{H}$ ). In contrast, in the inactive scenario, the projected summer phosphate peak surpassed the winter plateau. The highest integrated phosphate concentrations were projected in the inactive scenario $\left(60 \mu \mathrm{g} \mathrm{L}^{-1}\right)$, followed by the weakened scenario $\left(40 \mu \mathrm{g} \mathrm{L}^{-1}\right)$ and the regular and maximum scenarios (both about $35 \mu \mathrm{g} \mathrm{L}^{-1}$ ).

A

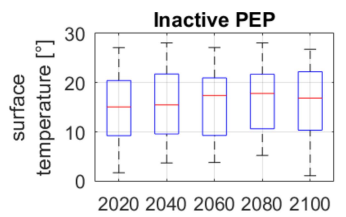

B

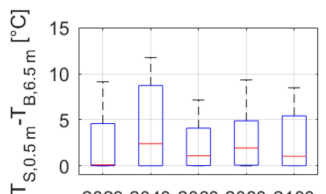

C

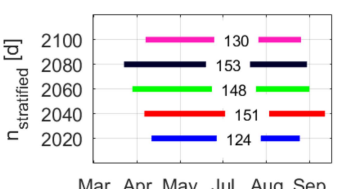

D

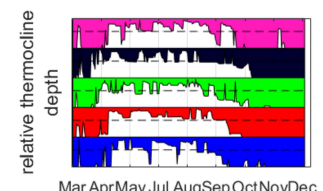

E
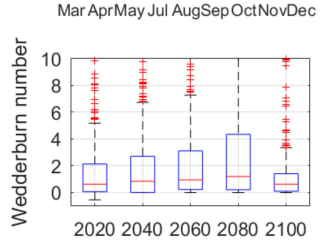

F

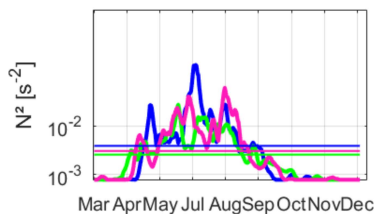

G

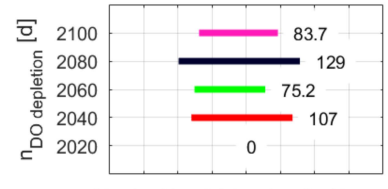

Mar Apr May Jul AugSep OctNov

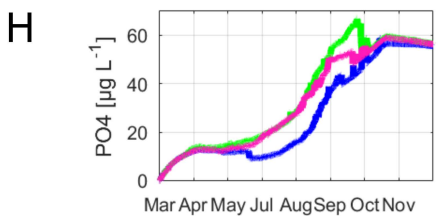

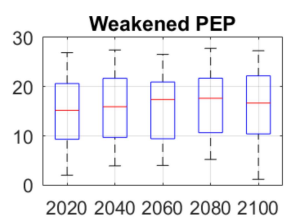
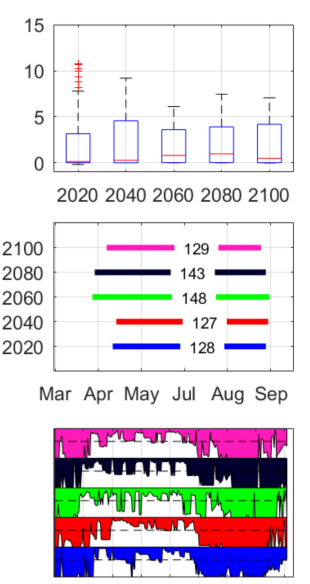

Mar AprMay Jul AugSep Oct NovDec

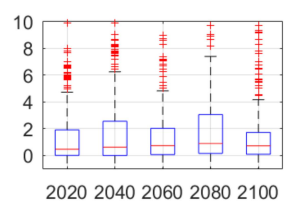

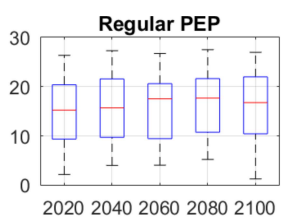
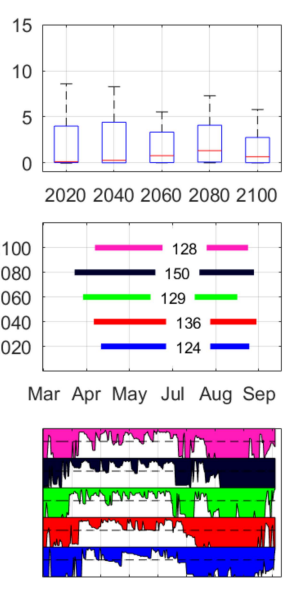

Mar AprMay Jul AugSep OctNovDec

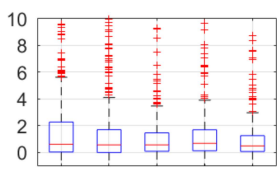

(a)

20202040206020802100
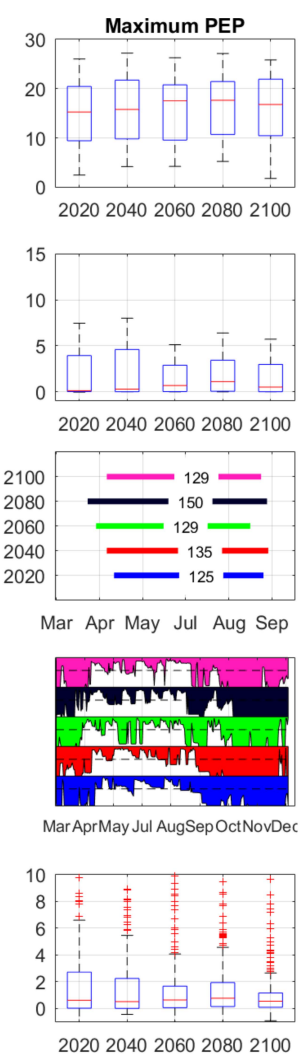
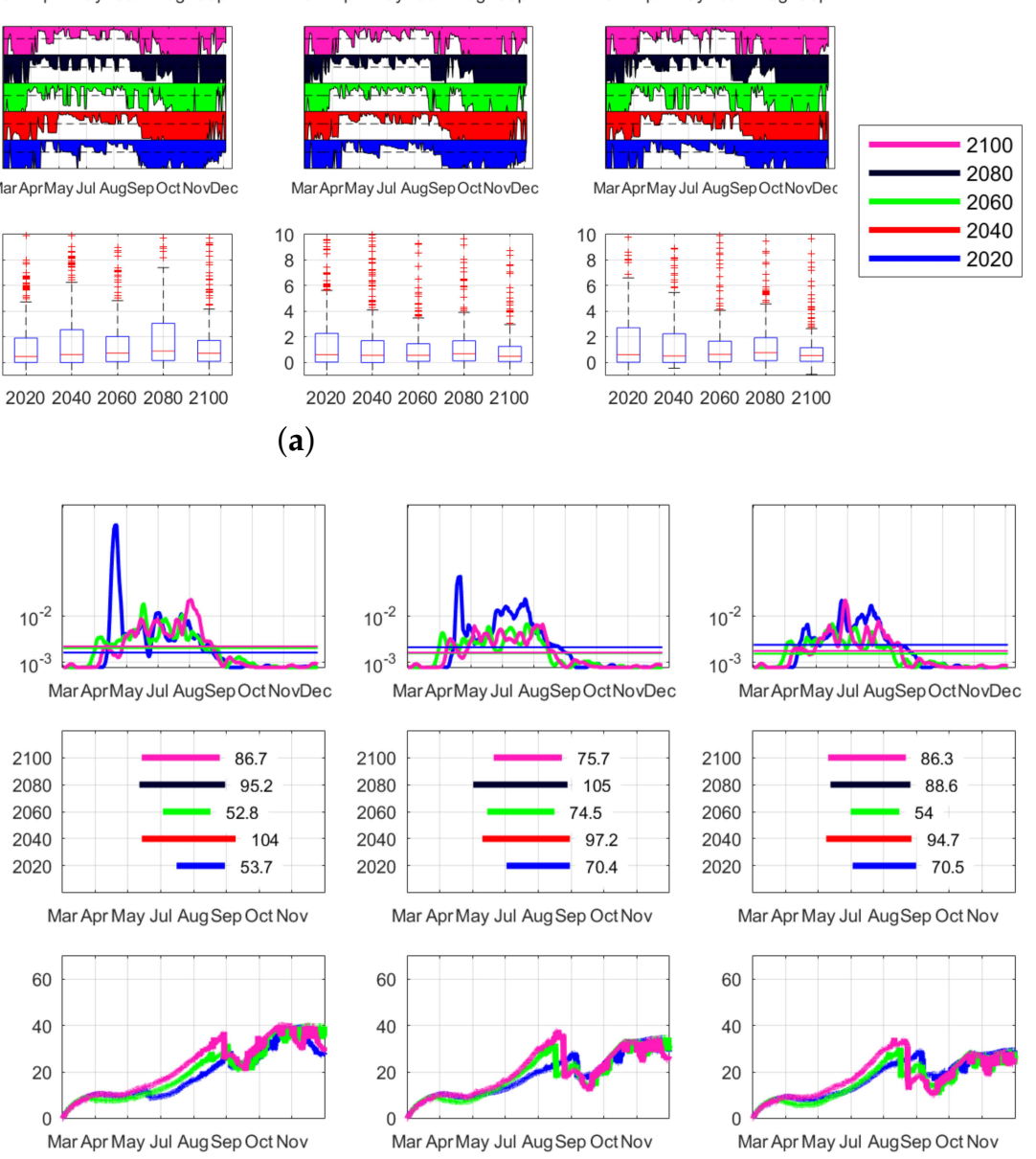

(b)

Figure 6. Evaluation of scenarios dealing with climate change and alternative management setups for 2020, 2040, 2060, 2080 and 2100 running from March 15 to December 31. "Inactive" ' represents a phosphorus 
elimination plant (PEP) scenario with no discharge, "Weakened" represents a decreased inflow of the PEP, "Regular" represents PEP discharges similar to those of 2008-2014, and "Maximum" represents a PEP scenario with a constant high discharge. Box plots summarize all daily values of the respective parameter and year; the central line indicates the median; the bottom and top edges of the box indicate the 25th and 75th percentiles, respectively; and the whiskers represent the most extreme data not considered as outliers: (A) boxplots of surface water temperatures $\left({ }^{\circ} \mathrm{C}\right)$ at $0.5 \mathrm{~m}$; $(\mathbf{B})$ boxplots of water temperature differences $\left({ }^{\circ} \mathrm{C}\right)$ between surface $(0.5 \mathrm{~m})$ and the mean depth temperatures $(6.5 \mathrm{~m})$; (C) stratification duration (days); (D) relative depth of thermocline between 0 and 1, where the black dashed line represents the mean depth $(6.5 \mathrm{~m})$; (E) boxplots of Wedderburn number; (F) buoyancy frequency $\left(\mathrm{s}^{-2}\right)$ filtered by a moving average filter over a window of 7 days; the vertical lines represent the respective mean buoyancy frequency including only values greater than zero; $(\mathrm{G})$ duration of oxygen depletion in deeper layers (days) (in a depth from 10 to $15 \mathrm{~m}$ ); (H) vertical integrated phosphate concentrations $\left(\mu \mathrm{g} \mathrm{L}^{-1}\right)$.

\section{Discussion}

\subsection{Model Application}

We considered the application of GLM-AED2 to Lake Tegel as being successful in replicating the essential processes of the lake system, namely, the lake stratification as expressed by the water temperatures as well as the seasonal patterns of the inorganic nutrients nitrate and phosphate. Although the ratio $R$ of the internal Rossby radius to the lake width, the lake number and a prior 1D model study [44] suggested that the 1D assumption was valid for the lake, the system is still characterized by a complex hydrodynamic situation including two hydraulically and chemically diverse inflows, a dendritic morphometry, wind-induced mixing events [45] and an intense water management system. These stochastic, rapid and mostly temporary factors (particularly wind-induced mixing), combined with the fact that the observed field data of the deepest site does not represent the whole lake basin and spatial variations are to be expected, likely induced most discrepancies between the observed and simulated data. There were only minor differences between the calibrated and the validated years, which suggested a good model stability and the feasibility of our conceptual model for Lake Tegel. The CMA-ES algorithm achieved very good water temperature fits, and we advise the utilization of automatic calibration techniques for future lake modeling studies. Whereas the RMSE and NSE criteria of water temperatures for the calibration and validation years illustrated a very good fit, the model still had minor discrepancies simulating the water temperatures in deep layers. These simulated deep water temperature discrepancies were in agreement with other studies that have investigated the sensitivity of GLM [20,22]. As a result of their high sensitivity, two important calibration variables were the inflow factors for the River Havel and PEP inflows, which were decreased or increased, respectively, during the automatic first calibration step. This was done to ensure a weaker impact of the River Havel on Lake Tegel compared to the inflow of the PEP. However, the inflow factor is a direct multiplier for the prescribed discharges of the respective boundary condition and therefore affects the water budget and the hydrodynamics (e.g., flow velocity) as well as the loadings. This can cause a strong model overfitting and an overrepresentation of the PEP inflow. We kept the calibrated inflow factors to investigate the application of the automatic calibration algorithm on the Lake Tegel model and because the fit between field and simulated data was valid. Nonetheless, future work has to be done to investigate sophisticated criteria for the range of the model variables.

The model was capable of sufficiently replicating the oxygen budget of Lake Tegel with a NSE of between 0.5 and 0.6 for most years. The surface oxygen concentrations in the year 2013 were strongly overestimated, which resulted in a NSE of 0.2. Although the negative NSE for nitrate and phosphate suggested that the mean concentration would be a better predictor than the model, our simulation was still capable of reproducing seasonal patterns of nitrate, phosphate and dissolved 
oxygen concentrations, particularly the depletion of dissolved oxygen and nitrate concentrations, during summer. This good replication was confirmed by the RMSE criteria of the biogeochemical parameters, which suggested a good fit with either a low RMSE for nitrate of under $0.5 \mathrm{mg} \mathrm{L}^{-1}$ or a low RMSE for phosphate of between 2 and $30 \mu \mathrm{g} \mathrm{L}^{-1}$. Processes weakly mirrored by the model were the patterns of surface dissolved oxygen concentrations. This was related to the simple configuration of the ecological module likely underestimating the primary production during summer and the simple atmosphere oxygen flux module. An intense calibration for phytoplankton variables and the inclusion of additional phytoplankton species in the model could help to improve the overall oxygen budget. Contrary to the field data, our model suggested a depletion of bottom nitrate during summer as a result of anaerobic conditions. This was caused by the dependence of the nitrate sediment flux on the basis of the abundance of bottom dissolved oxygen. Recent studies have implemented a more sophisticated coupling of GLM to a geochemical sediment model [68], which could help to improve the accurate simulation of sediment-water fluxes at Lake Tegel in the future.

The implementation of the wind penalizing filter did not improve the simulation results, and for future applications, the singular use of one inflow parameter is sufficient. Our assumption that the model calibration would suggest a higher value for months that favored mixing events (January, March, April, May and October) compared to the other months was not confirmed. The implementation of such a dynamic wind boundary could be interesting for future studies investigating similar systems that are heavily influenced by wind-induced mixing processes.

\subsection{Assessment of Scenarios}

The climate change scenario projected a prolongation of the stratified summer period in future years. This prolongation was in agreement with other studies, which have showed that climate change will eventually change the stratification patterns of lakes $[17,69,70]$. Additionally, all scenarios showed that the median as well as minimum and maximum annual surface water temperatures of the 25th and 75th percentiles will increase in the near future. The latter half of the 21st century depicted the highest median annual surface water temperature, while at the end of the century, the median slightly decreased. As explained before, the A1B scenario assumed a peak of human development in the middle of the 21st century, as well as technological innovations. Therefore, the WETTREG2010 data for projected air temperatures were stagnating in the latter half of the 21st century, further causing the surface lake water temperatures to slightly drop compared to the other simulated years. Taking the assumptions by the A1B emission scenario for Lake Tegel, the strongest impact of climate change on the hydrodynamics and the lake ecosystem can presumably happen between 2050 and 2080. Afterwards, the conditions of Lake Tegel can oscillate back to the current conditions. Therefore, the impact of climate change on Lake Tegel under emission scenario A1B can be the strongest in the second half of the 21st century.

The management scenarios projected a shift of the lake state in the inactive scenario, for which the winter stratification vanished. This suggested that Lake Tegel could shift from a dimictic towards a monomictic state, because of the deactivation of the PEP. This general shift from a dimictic to a warm monomictic state was also shown to be the possible fate for other lakes in local proximity to Lake Tegel [16]. Whether or not the PEP discharges are high or low, the elongation of the summer stratification period can severely increase the duration of a bottom oxygen depletion in Lake Tegel. This depletion of oxygen will affect the Lake Tegel ecosystem and redox reactions at the sediment. An increase in the buoyancy frequency can indicate conditions favoring the growth of cyanobacteria. Here, a buoyancy frequency of over $10^{-4} \mathrm{~s}^{-2}$ is a critical limit for benefiting cyanobacteria dominance [71]. The critical buoyancy frequency was surpassed during summer in all management scenarios. However, the formation of cyanobacteria blooms also depends on other hydrological and ecological factors, for instance, the water retention time, the availability of nutrients and the dominant phytoplankton structures [72]. Nonetheless, we argue that the projected physical lake variables, water temperature difference and buoyancy frequency, as well as the increased surface 
water temperatures due to climate change, can favor the formation of cyanobacteria blooms in the future in Lake Tegel. Further, the management scenario with nonexistent discharges of the PEP also projected increased concentrations of phosphate in the water column, further favoring the possible formation of cyanobacteria. As explained previously, future water quality studies on Lake Tegel should focus on the simulation of cyanobacteria and highlight the trophic interactions between different phytoplankton species.

The differences between the weakened, regular and maximum management scenarios regarding stratification patterns, stratification strength, thermocline deepening, buoyancy frequency and the concentrations of oxygen as well as phosphate were marginal. We showed that any active discharge regime of the elimination plant was a beneficial factor to the lake system by (a) acting as a buffer to nutrient-rich river inflows by discharging phosphate-poor waters, and (b) causing a weaker summer stratification compared to the inactive scenario. Without the PEP discharges acting as a dilluting factor, Lake Tegel could be heavily influenced by discharges of the River Havel. The result of this was increased phosphate concentrations in conjunction with a slightly higher buoyancy frequency that could potentially benefit the formation of cyanobacteria blooms. The mechanism behind the slightly increased summer stability in the inactive scenario compared to the other scenarios was likely a feedback loop between increased nutrient concentrations and a resulting higher turbidity (changes in water clarity), similarly to the results of a study conducted by Rose et al. [20]. Rose et al. stated that the thermal structure of lakes with a similar depth to Lake Tegel is sensitive to changes in water clarity, because "[...] the surface temperature may have warmed faster and deeper waters more slowly than they would have if water clarity had not increased" [20] (p 50). In our model, increased loadings of inorganic nutrients, for instance, phosphate, by the river inflow caused an earlier diatom bloom in the model and a subsequent increase in the light extinction coefficient/turbidity. This resulted in a decreased heat flux to the deeper water layers and thereby lower water temperatures. Additionally, the inflow of denser and warmer waters from the elimination plant was absent, which would otherwise further intrude into deeper lake layers, effectively increasing the water temperatures.

The results of the projected thermocline depths did show that the thermal lake stratification was not particularly distinctive and resulted in the formation of a relatively thin epilimnion. In the numerical model, wind-induced mixing or convective cooling events could easily deepen the thermocline at Lake Tegel. In particular, the weakened as well as the maximum management scenarios depicted several strong mixing events during summer, in which the thermocline nearly reached the maximum depth of Lake Tegel. Theses short summer mixing events can have a high relevance for future management: during these mixing events, internally released nutrients from the sediment could be transported to the surface water layers and could cause eutrophication. On the other hand, these thermocline deepening events could also transport dissolved oxygen into the hypolimnion. The management scenarios with a weakened or inactive PEP projected future lower and stagnant bottom water temperatures as a result of a stronger heating of the surface layer and a subsequent increased stability of the water column during the summer stratification period. For the latter half of the 21st century, the surface water temperatures were following the air temperature, and the bottom temperatures experienced less variance and did not drop below $5^{\circ} \mathrm{C}$. The stagnant water temperatures and the oxygen depletion could eventually negatively affect the ecosystem [16].

Important limitations of our study were the uncertainties associated to (1) the field data, (2) our conceptual model of Lake Tegel, (3) the GLM-AED2 model, (4) the projected weather data, and (5) the setup of alternative PEP management scenarios. The uncertainty due to field sampling and the data analysis could not be neglected. It could be a possible source for errors, but we minimized it by using transient and checked data by the same agency for each site. The uncertainties of the conceptual model and the simulation were minimized by calibrating and validating the model. A potential major source of uncertainty was the future climate projection by WETTREG2010. Although the regional data set was based on ECHAM5 and therefore on physical principles, the underlying assumptions of the A1B scenario as well as the stochastic nature of climate anomalies were still important sources for 
uncertainty. The last uncertainty was by choice: by only using simple future management scenarios, for instance, constant low and high values, we investigated the general response of Lake Tegel to climate change and management alterations. In reality, the PEP discharge is dependent on the upstream inflow of the WWTP, its respective catchment, the mode of operation of the lake pipeline and rainfall events. Therefore, steady discharge curves are highly idealized scenarios. Further, although recent reports have suggested an increase in total discharges as a result of climate change [73], we neglected the effect of climate change on the discharges of the flow boundary conditions and applied the same discharge curves for every future year. We also neglected the impact of an increasing frequency of extreme weather events on the lake system causing short-term high run-off and possible erosion events. These assumed simplifications should enable the model applications to focus on the effects of changing meteorological variables in conjunction with alternative management scenarios on the lake's thermal stratification and composition of oxygen as well as phosphate. Additionally, investigating factors such as increased surface and subsurface runoffs or complex inflow boundaries would extend the scope of this study and should be approached by coupling a catchment model to a hydrodynamic lake model.

\subsection{Implications for the Lake Water Management}

In the context of this study, we considered adaptive lake water management as a management that is not based on a fixed restoration strategy/management plan but one that "[...] recognizes the non-stationary nature of a system [...]" [74] (p 73). Because of the recent concerns regarding micropollutants in the urban water cycle of Berlin, particularly for Lake Tegel [24,77], there are future plans to divert the discharges of treated effluents from the upstream wastewater elimination plant away from Lake Tegel. In this case, the PEP could shut down as a result of the financial unfeasibility of operating a treatment plant and only treating discharges under the capacity. At the least, the discharges of the PEP into Lake Tegel would certainly decrease. However, as the results of our modeling study and former studies $[43,46]$ have suggested, the low phosphate discharges of the PEP have a diluting effect on the lake system. Decreasing these additional discharges can increase the phosphate concentrations in the water column. This can enable the formation of phytoplankton blooms and, later, increase water turbidity, further increasing the surface water temperatures. This vicious cycle has the potential to enhance the impact of climate change on the lake thermal stratification. Neglecting the economic unfeasibility of operating a PEP under capacity, using the lake pipeline to bypass water to the northeastern inflow for treatment has the potential to be an efficient measure to adapt the water management to climate change. The lake pipeline has a mean average flow of $0.65 \mathrm{~m}^{3} \mathrm{~s}^{-1}$ and can be increased to a maximum flow capacity of about $1.9 \mathrm{~m}^{3} \mathrm{~s}^{-1}$. This discharge then would be similar to the results of the weakened scenario and could counter the heavy loadings originating from the River Havel as well as the increased water column stability.

Another potentially useful strategy to adapt Lake Tegel's water management to climate change could make use of the hypolimnetic aerators at Lake Tegel, particularly under the condition that cyanobacteria would be established in Lake Tegel. Former studies have stated that the aerators cause a lifting of hypolimnetic waters into the epilimnion and, therefore, decrease the thickness of the metalimnion $[40,44]$. Artifical circulation measures are a widespread technique to avoid hypolimnetic oxygen depletion conditions and the formation of cyanobacteria blooms [75]. Although the installed aerators have the potential to cause more harm during future strong stratification events by transporting nutrients and oxygen-depleted waters from the hypolimnion to the epilimnion, destratification could also hinder the formation of toxic algae blooms. If these hypolimetic aerators could be modified to cause a complete mixing of the water column of Lake Tegel, they could have a positive effect in the latter half of the 21st century when the impact of climate change could be the strongest. Nonetheless, this management strategy also needs the additional discharges from the PEP; otherwise the aerators would only mix phosphate-rich waters into the hypolimnion. A combination of a still active PEP, even with low discharges, and artificial mixing or even oxygenation events could 
mitigate the projected severe impact of climate change on Lake Tegel's thermal structure as well as oxygen and phosphate composition in the latter half of the 21st century.

Although there is a wide range of in-lake management measures to control internal nutrient release from the sediment or to manipulate the water column stability $[75,76]$, the best long-term management measure to prevent a future eutrophication of Lake Tegel is the reduction of external loadings of phosphate originating from the River Havel [77]. Particularly as a result of climate change, a future reduction of the nutrient availability in lakes can become crucial because of its positive feedback on eutrophication [78]. Our study demonstrated that the inflow of the PEP can be efficient enough without artificial destruction of stratification. According to Schimmelpfennig et al. [46], an effective management strategy should consider the reduction of the nutrient input combined with the redirection of the wastewater discharge to the River Havel by "reverse" application of the pipeline (flow from PEP to the River Havel). This would require a long-term strategy of regulating the agriculture in the catchment. In the meanwhile, the PEP appears to be effective in mitigating the negative effects of climate change and should be kept active in the next decades.

\section{Conclusions}

Our 1D vertical model coupled to a water quality configuration was applicable to the evaluation of water management scenarios for Lake Tegel. According to projections made by the 1D model and using a realization of future meteorological conditions projected by WETTREG2010, Lake Tegel's annual stratification patterns will change as a result of climate change. The winter stratification will decrease, whereas the summer stratification will intensify. Additional nutrient-free discharges by an active elimination plant can mitigate an increase in the stability of the summer stratification period. Lake Tegel could potentially even shift from a dimitic seasonal-mixing type to a monomictic type. Ultimately, these physical changes will affect the lake's water quality. An increased summer stratification period combined with a higher buoyancy frequency will act as a favorable habitat for the formation of cyanobacteria blooms. Nonetheless, our study has showed that the elimination plant acts as an important "life-support system" for Lake Tegel, because the discharges from the plant act as a buffer against nutrient-rich waters from the River Havel. We conclude that the urban lake management system, similarly to reservoirs, has the potential to mitigate some of the manifold effects of climate change on an urban lake ecosystem, and a sophisticated adaption of management measures is required to deal with future challenges.

Acknowledgments: The authors would like to thank Lena Heinrich, Thomas Rossoll, Katrin Preuß and Christiane Herzog for providing technical and analytical support. We are grateful to Sylvia Jordan, Sebastian Schimmelpfennig, Antje Köhler, Ingrid Chorus, Thomas Pflugbeil, Tom Shatwell and Elena Matta for helpful discussions, feedback and criticism regarding the concept of the study and the modeling implications. Matt Hipsey, Louise Bruce and Luke Winslow shared modeling expertise for GLM and AED2. We thank Thomas Mehner and the participants of the workshop "Scientific Writing" at the Leibniz Institute of Freshwater Ecology and Inland Fisheries for helpful discussions on an early stage of the manuscript. Further, we would like to thank all agencies that provided data to us: the Senate of Berlin, the Berlin Water Company (BWB), the German Meteorological Office (DWD) and the German Federal Environment Agency (UBA). WETTREG2010 was developed by Meteo-Research under contract to the German Federal Environment Agency, 2006. We thank the two anonymous reviewers whose comments helped to improve and clarify this manuscript. This research was partly supported by the River Fund of the River Foundation of Japan; the Collaborative Research Project of International Institute for Okinawan Studies, University of the Ryukyu, Okinawa, Japan; and the Lab-to-Lab project of Saitama University, Saitama, Japan. This paper is a result of the project T4, carried out as part of the Research Training Group "Urban Water Interfaces (UWI)" (GRK 2032/1), which is funded by the German Research Foundation (DFG). The publication of this article was funded by the Open Access Fund of the Leibniz Association and by the Open Access Fund of the Leibniz-Institute of Freshwater Ecology and Inland Fisheries.

Author Contributions: R.L. and R.H. conceived and designed the calibration procedure and the model setup. G.K. and E.F. gave support regarding the theoretical background of lake physics and the formulation of the conceptual model. R.L., E.F. and M.H. analyzed the data. R.L. and M.H. conducted the field work. R.L. wrote the manuscript. All authors contributed to the discussion of the results and the proofreading of the manuscript. 
Conflicts of Interest: The authors declare no conflict of interest. The founding sponsors had no role in the design of the study; in the collection, analyses, or interpretation of data; in the writing of the manuscript, or in the decision to publish the results.

\section{Abbreviations}

The following abbreviations are used in this manuscript:

$\begin{array}{ll}\text { AED2 } & \text { Aquatic Ecodynamics Model Library } \\ \text { CMA-ES } & \text { Covariance Matrix Adaption Evolution Strategy } \\ \text { DOC } & \text { Dissolved organic carbon } \\ \text { EE } & \text { Elementary effect } \\ \text { GLM } & \text { General Lake Model } \\ \text { NRMSE } & \text { Normalized root-mean-square error } \\ \text { NSE } & \text { Nash-Sutcliffe coefficient of efficiency } \\ \text { PEP } & \text { Phosphorus elimination plant } \\ \text { POC } & \text { Particulate organic carbon } \\ \text { RMSE } & \text { Root-mean-square error } \\ \text { WETTREG } & \text { Wetterlagen-basierte Regionalisierungsmethode (regionalization method) } \\ \text { WWTP } & \text { Wastewater treatment plant }\end{array}$

\section{Appendix A}

\section{Calibration of physical and biogeochemical variables}

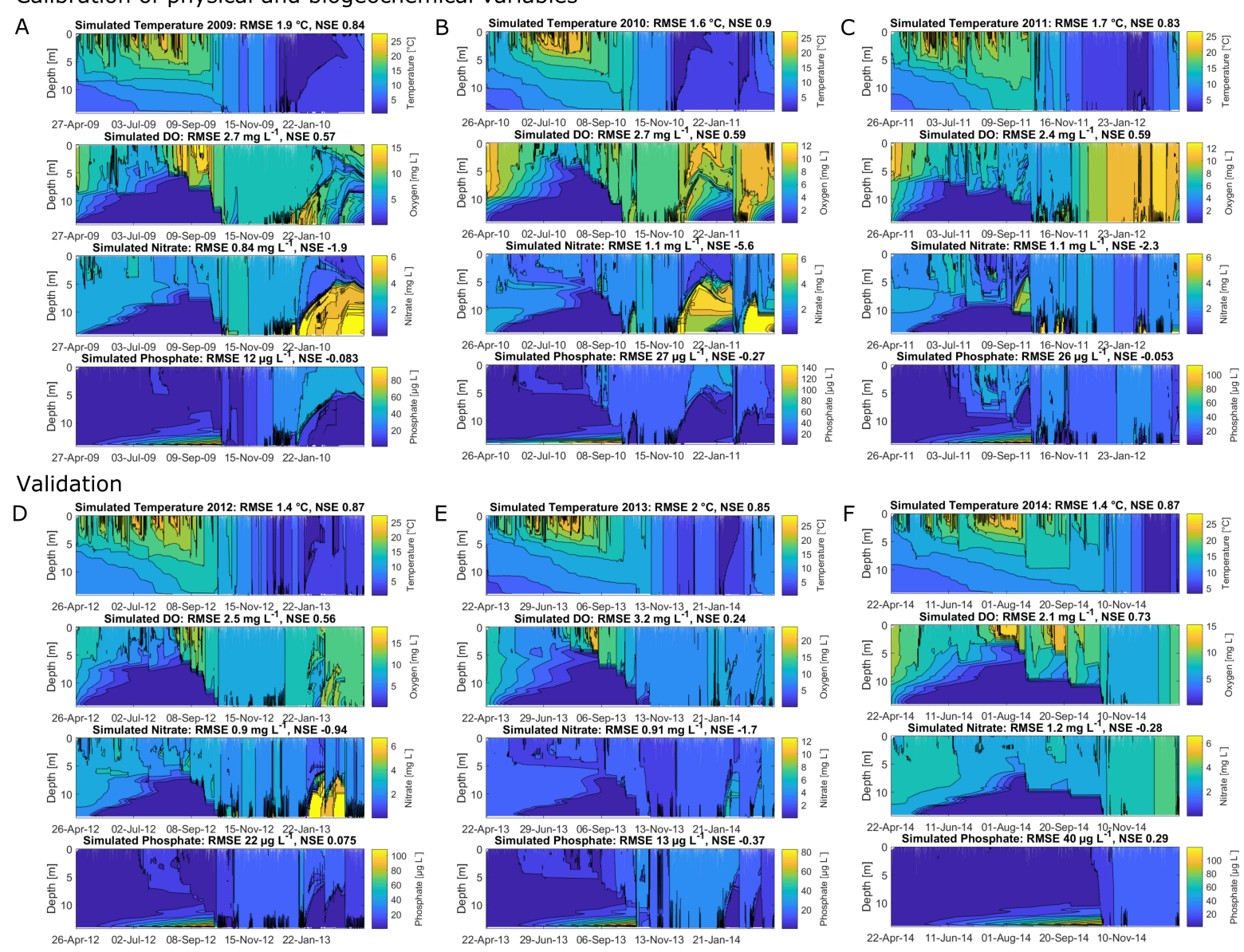

Figure A1. Contour plots expressing the model performance of water temperature $\left({ }^{\circ} \mathrm{C}\right)$, dissolved oxygen $\left(\mathrm{mg} \mathrm{L}^{-1}\right)$, nitrate $\left(\mathrm{mg} \mathrm{L}^{-1}\right)$ and phosphate concentrations $\left(\mu \mathrm{g} \mathrm{L}^{-1}\right)$; the calculated root-mean-square errors (RMSE) and Nash-Sutcliffe coefficients of efficiency (NSE) are given for the total water column: (A-C) calibrated years 2009, 2010 and 2011; (D-F) validated years 2012, 2013 and 2014. 
Table A1. Depth-specific root-mean-square errors for surface $(0.5 \mathrm{~m})$ and bottom $(14 \mathrm{~m})$ layers of water temperature $T\left({ }^{\circ} \mathrm{C}\right)$ and dissolved oxygen $D O\left(\mathrm{mg} \mathrm{L}^{-1}\right)$, nitrate $N\left(\mathrm{mg} \mathrm{L}^{-1}\right)$ and phosphate $P\left(\mu \mathrm{g} \mathrm{L}^{-1}\right)$ concentrations.

\begin{tabular}{lllllllll}
\hline Year & \multicolumn{4}{c}{ Surface } & \multicolumn{4}{c}{ Bottom } \\
\cline { 2 - 9 } & $\boldsymbol{T}$ & $\boldsymbol{D} \boldsymbol{O}$ & $\boldsymbol{N}$ & $\boldsymbol{P}$ & $\boldsymbol{T}$ & $\boldsymbol{D O}$ & $\boldsymbol{N}$ & $\boldsymbol{P}$ \\
\hline 2008 & 0.17 & 2.1 & 0.17 & 6.6 & 0.51 & 0.48 & 0.54 & 10 \\
2009 & 0.41 & 2.7 & 0.19 & 2.6 & 0.89 & 0.94 & 0.45 & 8.6 \\
2010 & 0.74 & 2.1 & 0.09 & 5.3 & 0.24 & 0.72 & 0.4 & 21 \\
2011 & 0.73 & 1.9 & 0.22 & 6.1 & 0.4 & 0.72 & 0.41 & 17 \\
2012 & 0.31 & 2.6 & 0.12 & 2.3 & 0.32 & 0.53 & 0.40 & 11 \\
2013 & 0.53 & 3.1 & 0.18 & 3.1 & 0.2 & 1.0 & 0.52 & 5.7 \\
2014 & 0.36 & 2.7 & 0.51 & 2.0 & 0.2 & 0.51 & 0.36 & 29 \\
\hline
\end{tabular}

\section{References}

1. Sala, O.E.; Chapin, F.S.; Armesto, J.J.; Berlow, E.; Bloomfield, J.; Dirzo, R.; Huber-Sanwald, E.; Huenneke, L.F.; Jackson, R.B.; Kinzig, A.; et al. Global Biodiversity Scenarios for the Year 2100. Science 2000, 287, 1770-1774.

2. Walther, G.R.; Post, E.; Convey, P.; Menzel, A.; Parmesan, C.; Beebee, T.J.C.; Fromentin, J.M.; Hoegh-Guldberg, O.; Bairlein, F. Ecological responses to recent climate change. Nature 2002, 416, 389-395.

3. Whitehead, P.G.; Wilby, R.L.; Battarbee, R.W.; Kernan, M.; Wade, A.J. A review of the potential impacts of climate change on surface water quality. Hydrol. Sci. J. 2009, 54, 101-123.

4. Adrian, R.; O’Reilly, C.M.; Zagarese, H.; Baines, S.B.; Hessen, D.O.; Keller, W.; Livingstone, D.M.; Sommaruga, R.; Straile, D.; Van Donk, E.; et al. Lakes as sentinels of climate change. Limnol. Oceanogr. 2009, 54, $2283-2297$.

5. Jiménez Cisneros, B.; Oki, T.; Arnell, N.; Benito, G.; Cogley, J.; Döll, P.; Jiang, T.; Mwakalila, S. Climate Change 2014: Impacts, Adaptation, and Vulnerability. Part A: Global and Sectoral Aspects. Contribution of Working Group II to the Fifth Assessment Report of the Intergovernmental Panel on Climate Change; Cambridge University Press: Cambridge, UK, 2014; Chapter Freshwater Resources, pp. 229-269.

6. Landkildehus, F.; Søndergaard, M.; Beklioglu, M.; Adrian, R.; Angeler, D.G.; Hejzlar, J.; Papastergiadou, E.; Zingel, P.; Çakiroğlu, A.I.; Scharfenberger, U.; et al. Climate change effects on shallow lakes: Design and preliminary results of a cross-European climate gradient mesocosm experiment. Est. J. Ecol. 2014, 63, 71.

7. Grimm, N.B.; Faeth, S.H.; Golubiewski, N.E.; Redman, C.L.; Wu, J.; Bai, X.; Briggs, J.M. Global Change and the Ecology of Cities. Science 2008, 319, 756-760.

8. Abdel-Fattah, S.; Krantzberg, G. Commentary: Climate change adaptive management in the Great Lakes. J. Great Lakes Res. 2014, 40, 578-580.

9. Graham, N.E.; Georgakakos, K.P. Toward Understanding the Value of Climate Information for Multiobjective Reservoir Management under Present and Future Climate and Demand Scenarios. J. Appl. Meteor. Climatol. 2009, 49, 557-573.

10. Yasarer, L.M.W.; Sturm, B.S.M. Potential impacts of climate change on reservoir services and management approaches. Lake Reserv. Manag. 2016, 32, 13-26.

11. Jeppesen, E.; Meerhoff, M.; Davidson, T.A.; Trolle, D.; Søndergaard, M.; Lauridsen, T.L.; Beklioglu, M.; Brucet, S.; Volta, P.; González-Bergonzoni, I.; et al. Climate change impacts on lakes: An integrated ecological perspective based on a multi-faceted approach, with special focus on shallow lakes. J. Limnol. 2014, 73, doi:10.4081/jlimnol.2014.844.

12. O’Reilly, C.M.; Sharma, S.; Gray, D.K.; Hampton, S.E.; Read, J.S.; Rowley, R.J.; Schneider, P.; Lenters, J.D.; McIntyre, P.B.; Kraemer, B.M.; et al. Rapid and highly variable warming of lake surface waters around the globe. Geophys. Res. Lett. 2015, 42, 2015GL066235.

13. Havens, K.E.; Paerl, H.W. Climate Change at a Crossroad for Control of Harmful Algal Blooms. Environ. Sci. Technol. 2015, 49, 12605-12606.

14. Paerl, H.W. Mitigating Harmful Cyanobacterial Blooms in a Human- and Climatically-Impacted World. Life 2014, 4, 988-1012. 
15. Trolle, D.; Elliott, J.A.; Mooij, W.M.; Janse, J.H.; Bolding, K.; Hamilton, D.P.; Jeppesen, E. Advancing projections of phytoplankton responses to climate change through ensemble modelling. Environ. Model. Softw. 2014, 61, 371-379.

16. Kirillin, G. Modeling the impact of global warming on water temperature and seasonal mixing regimes in small temperate lakes. Boreal Environ. Res. 2010, 15, 279-293.

17. Sahoo, G.B.; Forrest, A.L.; Schladow, S.G.; Reuter, J.E.; Coats, R.; Dettinger, M. Climate change impacts on lake thermal dynamics and ecosystem vulnerabilities. Limnol. Oceanogr. 2016, 61, 496-507.

18. Magee, M.R.; Wu, C.H. Response of water temperatures and stratification to changing climate in three lakes with different morphometry. Hydrol. Earth Syst. Sci. 2017, 21, 6253-6274.

19. Zhang, W.; Xu, Q.; Wang, X.; Hu, X.; Wang, C.; Pang, Y.; Hu, Y.; Zhao, Y.; Zhao, X. Spatiotemporal Distribution of Eutrophication in Lake Tai as Affected by Wind Water 2017, 9, 200.

20. Rose, K.C.; Winslow, L.A.; Read, J.S.; Hansen, G.J.A. Climate-induced warming of lakes can be either amplified or suppressed by trends in water clarity. Limnol. Oceanogr. 2016, 1, 44-53.

21. Snortheim, C.A.; Hanson, P.C.; McMahon, K.D.; Read, J.S.; Carey, C.C.; Dugan, H.A. Meteorological drivers of hypolimnetic anoxia in a eutrophic, north temperate lake. Ecol. Model. 2017, 343, 39-53.

22. Read, J.S.; Winslow, L.A.; Hansen, G.J.; Van Den Hoek, J.; Hanson, P.C.; Bruce, L.C.; Markfort, C.D. Simulating 2368 temperate lakes reveals weak coherence in stratification phenology. Ecol. Model. 2014, 291, 142-150.

23. Gessner, M.; Hinkelmann, R.; Nützmann, G.; Jekel, M.; Singer, G.; Lewandowski, J.; Nehls, T.; Barjenbruch, M. Urban water interfaces. J. Hydrol. 2014, 514, 226-232.

24. Jekel, M.; Ruhl, A.; Meinel, F.; Zietzschmann, F.; Lima, S.; Baur, N.; Wenzel, M.; Gnirß, R.; Sperlich, A.; Dünnbier, U.; et al. Anthropogenic organic micro-pollutants and pathogens in the urban water cycle: Assessment, barriers and risk communication (ASKURIS). Environ. Sci. Eur. 2013, 25, 20.

25. Jeppesen, E.; Søndergaard, M.; Liu, Z. Lake Restoration and Management in a Climate Change Perspective: An Introduction. Water 2017, 9, 122.

26. Kaushal, S.S.; McDowell, W.H.; Wollheim, W.M.; Johnson, T.A.N.; Mayer, P.M.; Belt, K.T.; Pennino, M.J. Urban Evolution: The Role of Water. Water 2015, 7, 4063-4087.

27. Sahoo, G.B.; Schladow, S.G. Impacts of climate change on lakes and reservoirs dynamics and restoration policies. Sustain. Sci. 2008, 3, 189-199.

28. Garrote, L. Managing Water Resources to Adapt to Climate Change: Facing Uncertainty and Scarcity in a Changing Context. Water Resour. Manag. 2017, 31, 2951-2963.

29. Simonovic, S.P. Bringing Future Climatic Change into Water Resources Management Practice Today. Water Resour. Manag. 2017, 31, 2933-2950.

30. Goonetilleke, A.; Vithanage, M. Water Resources Management: Innovation and Challenges in a Changing World. Water 2017, 9, 281.

31. Wang, G.; Mang, S.; Cai, H.; Liu, S.; Zhang, Z.; Wang, L.; Innes, J.L. Integrated watershed management: evolution, development and emerging trends. J. For. Res. 2016, 27, 967-994.

32. Ludovisi, A.; Gaino, E.; Bellezza, M.; Casadei, S. Impact of climate change on the hydrology of shallow Lake Trasimeno (Umbria, Italy): History, forecasting and management. Aquat. Ecosyst. Health Manag. 2013, 16, 190-197.

33. Tzabiras, J.; Vasiliades, L.; Sidiropoulos, P.; Loukas, A.; Mylopoulos, N. Evaluation of Water Resources Management Strategies to Overturn Climate Change Impacts on Lake Karla Watershed. Water Resour. Manag. 2016, 30, 5819-5844.

34. Zhang, C.; Lai, S.; Gao, X.; Xu, L. Potential impacts of climate change on water quality in a shallow reservoir in China. Environ. Sci. Pollut. Res. 2015, 22, 14971-14982.

35. Germer, S.; Kaiser, K.; Bens, O.; Hüttl, R.F. Water Balance Changes and Responses of Ecosystems and Society in the Berlin-Brandenburg Region-A Review. DIE ERDE J. Geogr. Soc. Berlin 2011, 142, 65-95.

36. Andrew, J.T.; Sauquet, E. Climate Change Impacts and Water Management Adaptation in Two Mediterranean-Climate Watersheds: Learning from the Durance and Sacramento Rivers. Water 2017, 9, 126.

37. Fant, C.; Srinivasan, R.; Boehlert, B.; Rennels, L.; Chapra, S.C.; Strzepek, K.M.; Corona, J.; Allen, A.; Martinich, J. Climate Change Impacts on US Water Quality Using Two Models: HAWQS and US Basins. Water 2017, 9, 118.

38. Schauser, I.; Chorus, I. Assessment of internal and external lake restoration measures for two Berlin lakes. Lake Reserv. Manag. 2007, 23, 366-376. 
39. Hilt, S.; Van de Weyer, K.; Köhler, A.; Chorus, I. Submerged Macrophyte Responses to Reduced Phosphorus Concentrations in Two Peri-Urban Lakes. Restor. Ecol. 2010, 18, 452-461.

40. Heinzmann, B.; Chorus, I. Restoration concept for Lake Tegel, a major drinking and bathing water resource in a densely populated area. Environ. Sci. Technol. 1994, 28, 1410-1416.

41. Kleeberg, A.; Köhler, A.; Hupfer, M. How effectively does a single or continuous iron supply affect the phosphorus budget of aerated lakes? J. Soils Sediments 2012, 12, 1593-1603.

42. Ladwig, R.; Heinrich, L.; Singer, G.; Hupfer, M. Sediment core data reconstruct the management history and usage of a heavily modified urban lake in Berlin, Germany. Environ. Sci. Pollut. Res. 2017, 24, 25166-25178.

43. Schauser, I.; Chorus, I. Water and phosphorus mass balance of Lake Tegel and Schlachtensee-A modelling approach. Water Res. 2009, 43, 1788-1800.

44. Lindenschmidt, K.E.; Hamblin, P.F. Hypolimnetic aeration in Lake Tegel, Berlin. Water Res. 1997, 31, $1619-1628$.

45. Schimmelpfennig, S.; Kirillin, G.; Engelhardt, C.; Nützmann, G. Effects of wind-driven circulation on river intrusion in Lake Tegel: Modeling study with projection on transport of pollutants. Environ. Fluid Mech. 2012, 12, 321-339.

46. Schimmelpfennig, S.; Kirillin, G.; Engelhardt, C.; Nützmann, G.; Dünnbier, U. Seeking a compromise between pharmaceutical pollution and phosphorus load: Management strategies for Lake Tegel, Berlin. Water Res. 2012, 46, 4153-4163.

47. Read, J.S.; Hamilton, D.P.; Jones, I.D.; Muraoka, K.; Winslow, L.A.; Kroiss, R.; Wu, C.H.; Gaiser, E. Derivation of lake mixing and stratification indices from high-resolution lake buoy data. Environ. Model. Softw. 2011, 26, 1325-1336.

48. Patterson, J.C.; Hamblin, P.F.; Imberger, J. Classification and dynamic simulation of the vertical density structure of lakes1. Limnol. Oceanogr. 1984, 29, 845-861.

49. Gill, A. Atmosphere-Ocean Dynamics; Academic Press: Cambridge, MA, USA, 1982.

50. Robertson, D.M.; Imberger, J. Lake Number, a Quantitative Indicator of Mixing Used to Estimate Changes in Dissolved Oxygen. Int. Rev. Hydrobiol. 1994, 79, 159-176.

51. Imerito, A. Dynamic Reservoir Simulation Model DYRESM: v4.0 ScienceManual; Centre for Water Research, The University of Western Australia, Perth, Australia, 2015.

52. Hipsey, M.R.; Bruce, L.C.; Hamilton, D.P. General Lake Model-Model Overview and User Information v. 2.0; AED Report \#26, The University of Western Australia, Perth, Australia, 2014.

53. Hipsey, M.R.; Bruce, L.C.; Hamilton, D.P. Aquatic Ecodynamics (AED) Model Library Science Manual, DRAFT v4; The University of Western Australia, Perth, Australia, 2013.

54. Chorus, I.; Schauser, I. Oligotrophication of Lake Tegel and Schlachtensee, Berlin-Analysis of System Components, Causalities and Response Thresholds Compared to Responses of Other Waterbodies; Federal Environment Agency: Dessau-Roßlau, Germany, 2011.

55. Tikhomirov, V.V. Hydrogeochemistry Fundamentals and Advances Volume 1: Groundwater Composition and Chemistry; John Wiley \& Sons: Hoboken, NJ, USA, 2016.

56. Morris, M.D. Factorial Sampling Plans for Preliminary Computational Experiments. Technometrics 1991, 33, 161-174.

57. Sohier, H.; Farges, J.L.; Piet-Lahanier, H. Improvement of the Representativity of the Morris Method for Air-Launch-to-Orbit Separation. IFAC Proc. Vol. 2014, 47, 7954-7959.

58. Hansen, N. The CMA Evolution Strategy: A Comparing Review. In Towards a New Evolutionary Computation; Number 192 in Studies in Fuzziness and Soft Computing; Lozano, J.A., Larrañaga, P., Inza, I., Bengoetxea, E., Eds.; Springer: Berlin/Heidelberg, Germany, 2006; pp. 75-102, doi: 10.1007/3-540-32494-1_4.

59. Kreienkamp, F.; Spekat, A.; Enke, W. Weiterentwicklung von WETTREG Bezüglich Neuartiger Wetterlagen; Technical Report; Climate \& Environment Consulting Potsdam GmbH: Potsdam, Germany, 2010.

60. Enke, W.; Spegat, A. Downscaling climate model outputs into local and regional weather elements by classification and regression. Clim. Res. 1997, 8, 195-207.

61. Spekat, A.; Enke, W.; Kreienkamp, F. Neuentwicklung von regional hoch aufgelösten Wetterlagen für Deutschland und Bereitstellung regionaler Klimaszenarios auf der Basis von globalen Klimasimulationen mit dem Regionalisierungsmodell WETTREG auf der Basis von globalen Klimasimulationen mit ECHAM5/MPI-OM T63L31 2010 bis 2100 für die SRES-Szenarios B1, A1B und A2; WETTREG: Forschungsprojekt im Auftrag des Umweltbundesamtes, Climate \& Environment Consulting Potsdam GmbH, Potsdam, Germany, 2007. 
62. SRES, I.; Nakičenovič, N.; Swart, R. Special Report on Emissions Scenarios: A Special Report of Working Group III of the Intergovernmental Panel on Climate Change; Cambridge University Press: Cambridge, UK, 2010.

63. Engelhardt, C.; Kirillin, G. Criteria for the onset and breakup of summer lake stratification based on routine temperature measurements. Fundam. Appl. Limnol./Arch. Hydrobiol. 2014, 184, 183-194.

64. Wilhelm, S.; Adrian, R. Impact of summer warming on the thermal characteristics of a polymictic lake and consequences for oxygen, nutrients and phytoplankton. Freshw. Biol. 2008, 53, 226-237.

65. Thompson, R.; Imberger, J. Response of a Numerical of a Stratified Lake to Wind Stress. In Proceedings of the International Symposium on Stratified Flows, Trondheim, Norway, 24-27 June 1980.

66. Kirillin, G.; Shatwell, T. Generalized scaling of seasonal thermal stratification in lakes. Earth-Sci. Rev. 2016, 161, 179-190.

67. Reynolds, C. Vegetation Processes in the Pelagic: A Model for Ecosystem Theory; Excellence in Ecology, Vol. 9, Ecology Institute: Oldendorf/Luhe, Germany, 1997

68. Salmon, S.U.; Hipsey, M.R.; Wake, G.W.; Ivey, G.N.; Oldham, C.E. Quantifying Lake Water Quality Evolution: Coupled Geochemistry, Hydrodynamics, and Aquatic Ecology in an Acidic Pit Lake. Environ. Sci. Technol. 2017, 51, 9864-9875.

69. Jeppesen, E.; Kronvang, B.; Meerhoff, M.; Søndergaard, M.; Hansen, K.M.; Andersen, H.E.; Lauridsen, T.L.; Liboriussen, L.; Beklioglu, M.; Özen, A.; et al. Climate Change Effects on Runoff, Catchment Phosphorus Loading and Lake Ecological State, and Potential Adaptations. J. Environ. Qual. 2009, 38, 1930-1941.

70. Rolighed, J.; Jeppesen, E.; Søndergaard, M.; Bjerring, R.; Janse, J.H.; Mooij, W.M.; Trolle, D. Climate Change Will Make Recovery from Eutrophication More Difficult in Shallow Danish Lake Søbygaard. Water 2016, 8, 459 .

71. Furusato, E.; Asaeda, T. The relation between the type of antenna pigments of dominant cyanobacteria and the ambient stratification condition in reservoirs. Rep. Res. Edu. Ctr. Inlandwat. Environ. 2004, 2, 97-103.

72. Journey, C.A.; Beaulieu, K.M.; Bradley, P.M. Environmental Factors that Influence Cyanobacteria and Geosmin Occurrence in Reservoirs. In Current Perspectives in Contaminant Hydrology and Water Resourcres Sustainability; InTech: London, UK, 2013.

73. Reusswig, F.; Becker, C.; Lass, W.; Haag, L.; Hirschfeld, J.; Knorr, A.; Lüdeke, M.K.; Neuhaus, A.; Pankoke, C.; Rupp, J.; et al. Anpassung an die Folgen des Klimawandels in Berlin (AFOK). Klimaschutz Teilkonzept. Hauptbericht. Gutachten im Auftrag der Senatsverwaltung für Stadtentwicklung und Umwelt; Technical Report; Sonderreferat Klimaschutz und Energie (SRKE), Senatsverwaltung für Stadtentwicklung und Umwelt: Potsdam/Berlin, Germany, 2016.

74. Imberger, J.; Marti, C.L.; Dallimore, C.; Hamilton, D.; Escriba, J.; Valerio, G. Real-time, adaptive, self-learning management of lakes. In Proceedings of the 37th IAHR World Congress, Kuala Lumpur, Malaysia, 13-18 August 2017, 2017; pp. 73-86.

75. Visser, P.M.; Ibelings, B.W.; Bormans, M.; Huisman, J. Artificial mixing to control cyanobacterial blooms: A review. Aquat. Ecol. 2016, 50, 423-441.

76. Bormans, M.; Marsalek, B.; Jancula, D. Controlling internal phosphorus loading in lakes by physical methods to reduce cyanobacterial blooms: A review. Aquat. Ecol. 2016, 50, 407-422.

77. Schimmelpfennig, S.; Kirillin, G.; Engelhardt, C.; Dünnbier, U.; Nützmann, G. Fate of pharmaceutical micro-pollutants in Lake Tegel (Berlin, Germany): The impact of lake-specific mechanisms. Environ. Earth Sci. 2016, 75, 893.

78. Matzinger, A.; Schmid, M.; Veljanoska-Sarafiloska, E.; Patceva, S.; Guseska, D.; Wagner, B.; Müller, B.; Sturm, M.; Wüest, A. Eutrophication of ancient Lake Ohrid: Global warming amplifies detrimental effects of increased nutrient inputs. Limnol. Oceanogr. 2007, 52, 338-353.

(C) 2018 by the authors. Licensee MDPI, Basel, Switzerland. This article is an open access article distributed under the terms and conditions of the Creative Commons Attribution (CC BY) license (http:/ / creativecommons.org/licenses/by/4.0/). 